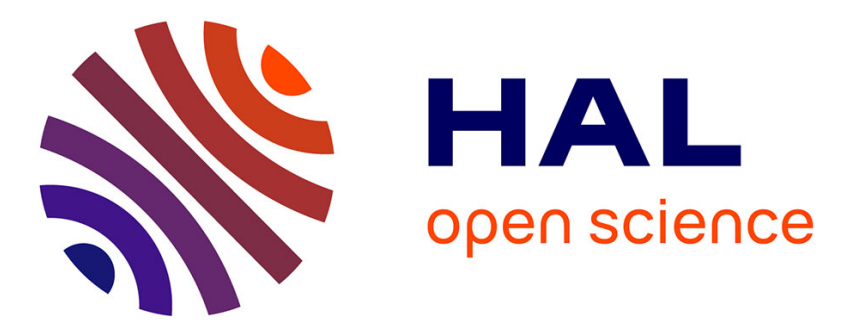

\title{
Crustal and lithospheric structure of the Alborz Mountains (Iran) and surrounding areas from integrated geophysical modeling
}

S.H. Motavallianbaran, H. Zeyen, Marie Françoise Brunet, V. Ebrahimzadeh Ardestani

\section{To cite this version:}

S.H. Motavallianbaran, H. Zeyen, Marie Françoise Brunet, V. Ebrahimzadeh Ardestani. Crustal and lithospheric structure of the Alborz Mountains (Iran) and surrounding areas from integrated geophysical modeling. Tectonics, 2011, 30 (5), 10.1029/2011TC002934 . hal-00610278

\section{HAL Id: hal-00610278 \\ https://hal.science/hal-00610278}

Submitted on 18 May 2021

HAL is a multi-disciplinary open access archive for the deposit and dissemination of scientific research documents, whether they are published or not. The documents may come from teaching and research institutions in France or abroad, or from public or private research centers.
L'archive ouverte pluridisciplinaire HAL, est destinée au dépôt et à la diffusion de documents scientifiques de niveau recherche, publiés ou non, émanant des établissements d'enseignement et de recherche français ou étrangers, des laboratoires publics ou privés. 


\title{
Crustal and lithospheric structure of the Alborz Mountains, Iran, and surrounding areas from integrated geophysical modeling
}

\author{
Seyed-Hani Motavalli-Anbaran, ${ }^{1,2}$ Hermann Zeyen, ${ }^{1}$ Marie-Françoise Brunet, ${ }^{3,4}$ \\ and Vahid Ebrahimzadeh Ardestani ${ }^{2}$ \\ Received 3 May 2011; revised 3 July 2011; accepted 19 July 2011; published 13 October 2011.
}

[1] Using gravity, geoid, topography and surface heat flow data, we have modeled the density and temperature distribution in the lithosphere along three profiles crossing Iran in SW-NE direction from the Arabian foreland in the SW to the South Caspian Basin and the Turan Platform to the NE. We find thin lithosphere $(100-120 \mathrm{~km})$ underneath central Iran, whereas thick lithosphere (up to $240 \mathrm{~km}$ ) is found underneath Arabia, the South Caspian Basin and the Turan Platform. Crustal thickening is found under the Zagros and Alborz mountains (up to $60 \mathrm{~km}$ ) and under the Kopet-Dagh Mountains $(48 \mathrm{~km})$, whereas the thin crust under the southern Caspian Sea is either an oceanic crust or a highly thinned continental one. Below the South Caspian Sea, the shape of the crust-mantle interface and the base of the lithosphere indicate a subduction of the South Caspian block toward the N-NW. Further east, under the Kopet-Dagh, no evidence for active subduction is visible. This can be explained by a rheologically very strong South Caspian block, surrounded by weaker continental lithosphere.

Citation: Motavalli-Anbaran, S.-H., H. Zeyen, M.-F. Brunet, and V. E. Ardestani (2011), Crustal and lithospheric structure of the Alborz Mountains, Iran, and surrounding areas from integrated geophysical modeling, Tectonics, 30, TC5012, doi:10.1029/2011TC002934.

\section{Introduction}

[2] The tectonic evolution of northern Iran and the South Caspian Basin as well as its transition into the Scythian and Turan platforms is yet an unsolved and debated problem [Allen et al., 2003; Artyushkov, 2007; Berberian, 1983; Berberian and King, 1981; Brunet et al., 2009; Brunet et al., 2003; Devlin et al., 1999; Golonka, 2007; Kaz'min and Tikhonova, 2006; Mamedov, 2004; Natal'ina and Sengör, 2005; Saintot et al., 2006; Sengör, 1990; Stampfli and Borel, 2004; Zonenshain and Le Pichon, 1986; Zonenshain et al., 1990]. Important questions concern the crustal structure of the South Caspian Basin underneath its extremely thick sedimentary cover, the reason for the disappearing of the Caucasus relief in the Caspian Sea, and the origin of the Alborz Mountains and its crustal as well as lithospheric structure.

[3] In order to better understand the lithospheric structure of the area, we conducted a study of potential field data (gravity and geoid) constrained by topography along three profiles crossing the area roughly in SW-NE direction. The combination of these different kinds of data sets will help to reduce the uncertainty of the Moho depth and lithosphere-

${ }^{1}$ IDES, UMR 8148, Département des Sciences de la Terre, CNRS/ Université Paris-Sud XI, Orsay, France.

${ }^{2}$ Institute of Geophysics, University of Tehran, Tehran, Iran.

${ }^{3}$ ISTeP, UMR 7193, UPMC Université Paris 6, Paris, France.

${ }^{4}$ ISTeP, UMR 7193, CNRS, Paris, France.

Copyright 2011 by the American Geophysical Union. 0278-7407/11/2011TC002934 asthenosphere boundary along three $2 \mathrm{D}$ profiles and to determine the density distribution within the crust. The center of the region targeted in this paper is the Alborz stretching over $100 \mathrm{~km}$ in N-S direction and $600 \mathrm{~km}$ in E-W direction. It is surrounded by a complex setting of tectonic units including in our study area the South Caspian Basin, the Apsheron-Balkan Sill and Turan Platform in the north, central Iran and Zagros Mountains in the south and the Kopet-Dagh Mountains in the east (Figure 1).

\section{Geological and Geophysical Background}

[4] The study area includes several large-scale tectonic units (Figure 1). Our 2D profiles start in the foreland basin of the Arabia-Eurasia collision zone and cross the Zagros and central Iran to finish in the Turan Platform after crossing various units. After central Iran, profiles I and II cross the Alborz and the South Caspian Basin. Profile I then goes across the Apsheron-Balkan Sill and Kara Bogaz High, whereas profile II crosses the intermediate area between Apsheron-Balkan Sill and Kopet-Dagh through Ashgabat fault zone [e.g., [Hollingsworth et al., 2008; Lyberis and Manby, 1999]. Profile III passes through Binalud then Kopet-Dagh mountains and Kopet-Dagh foreland then in the western part of the Amu-Darya Basin (Figure 1).

[5] The area is generally subjected to the effects of the NNE-SSW convergence of the Arabian Plate with Eurasia. According to recent GPS surveys the rate of convergence is $\sim 22 \mathrm{~mm} / \mathrm{yr}$ of which, $\sim 8 \mathrm{~mm} / \mathrm{yr}$ are accommodated within the Zagros, $\sim 3 \mathrm{~mm} / \mathrm{yr}$ in central Iran, $\sim 5 \mathrm{~mm} / \mathrm{yr}$ in the Alborz and $\sim 6 \mathrm{~mm} / \mathrm{yr}$ by northwestward movement of the 


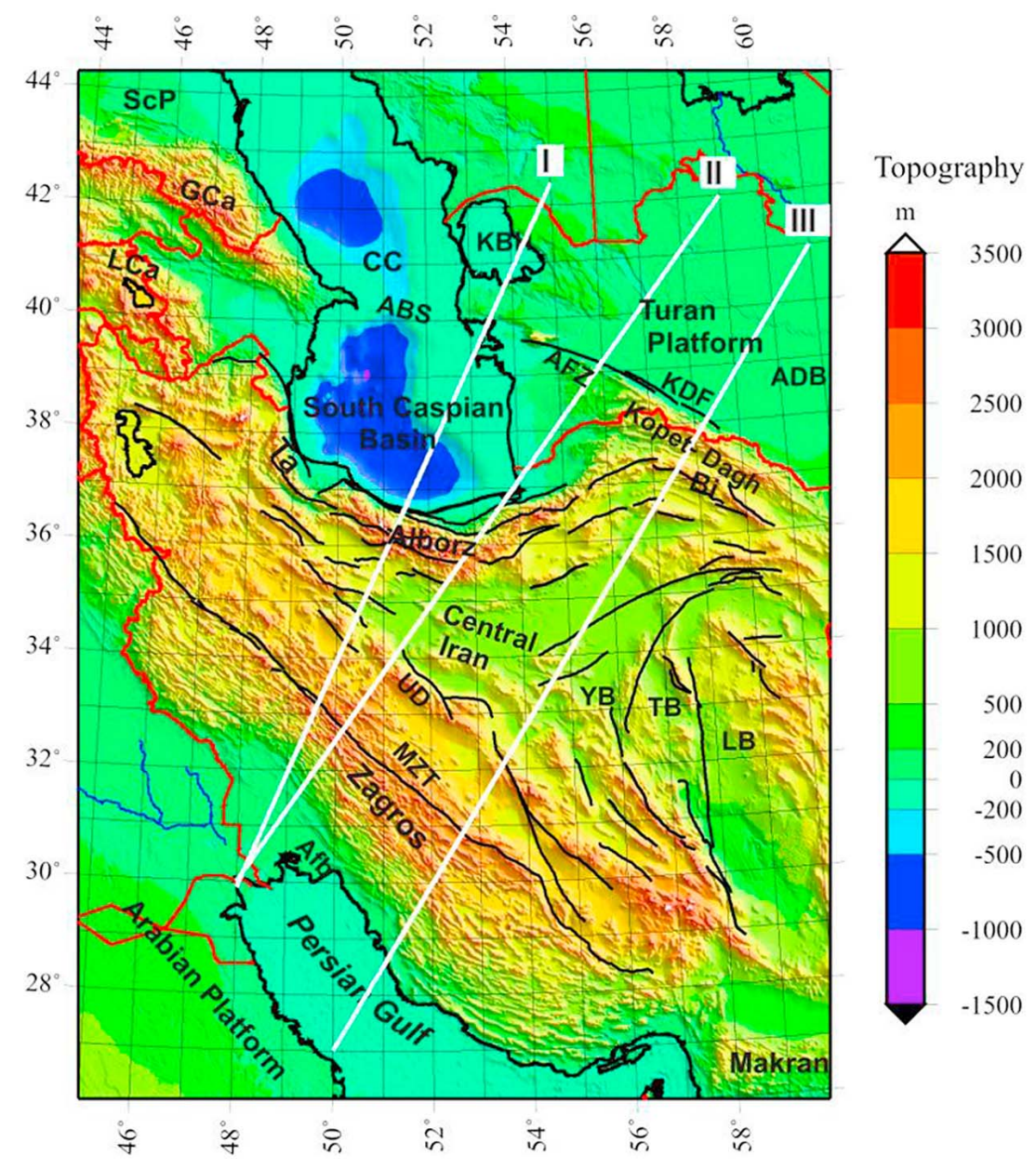

Figure 1. Location map of the principal structural units of the targeted area and of the three 2D profiles on top of an ETOPO1 topography map [Sandwell and Smith, 1997, 2009; ftp://topex.ucsd.edu/pub]. ABS, Apsheron Balkan Sill; ADB, Amu Darya Basin; Afb, Arabian foreland basin; AFZ, Ashgabat Fault Zone; Bi, Binalud Mountains; CC, Central Caspian; GCa, Greater Caucasus; KBH, Kara Bogaz High; KDF, Kopet-Dagh foreland basin; LB, Lut Block; LCa, Lesser Caucasus; MZT, Main Zagros Thrust; ScP, Scythian Platform; Ta, Talesh Mountains; TB, Tabas Block; UD, Urumieh Dokhtar magmatic arc; YB: Yazd block. Faults positions are taken from Hessami et al. [2003].

South Caspian related to stable Eurasia [Guest et al., 2007; Vernant et al., 2004a, 2004b].

[6] The main interest of our study concerns the AlborzKopet-Dagh-South Caspian area. In order to avoid boundary effects in our models, we prolonged the profiles into the adjacent tectonic units. Therefore, we present the principal areas in detail, and briefly treat the other areas.

\subsection{Zagros Mountains}

[7] The Zagros Mountains are a young and active collisional belt which is the result of subduction of the Arabian Plate underneath Iran (part of Eurasia) and the Cenozoic closure of the Neotethys Ocean [Barrier and Vrielynck, 2008; Barrier et al., 2008]. A finite element study at lithospheric scale has been published by Bird [1978] in this area. Bird concludes that the convergence between Arabia and Iran is no longer driven by a subducting oceanic slab but that this slab has broken off. A similar result has been found more recently by several studies: Molinaro et al. [2005a] by potential field modeling in the southeastern Zagros and also
Omrani et al. [2008] and Paul et al. [2010]. Combining independent information from mantle tomography and tectonic reconstructions, Hafkenscheid et al. [2006] proposed an early Oligocene age for the slab detachment underneath the northern Zagros suture zone, whereas Molinaro et al. [2005a] propose a late Miocene-Pliocene age.

[8] On crustal scale, gravity modeling by Dehghani and Makris [1984] suggested a crustal thickness of 50-55 km under the central Zagros similar to the $\sim 52 \mathrm{~km}$ modeled by Molinaro et al. [2005a] in the southeastern Zagros, whereas Snyder and Barazangi [1986], also based on gravity data, modeled a maximum Moho depth of $65 \mathrm{~km}$ for the Zagros Mountains. Based on a receiver function study, Hatzfeld et al. [2003] estimated a Moho depth of $46 \pm 2 \mathrm{~km}$ from a single station in central part of the Zagros. By interpreting data from a $620 \mathrm{~km}$ long receiver functions profile which crosses the Zagros, Paul et al. [2006] propose a crustal model with a maximum crustal thickness of $\sim 70 \mathrm{~km}$ underneath Sanandaj Sirjan Zone (SSZ). This thickening is located 50-90 km NE of the exposed surface of Main Zagros Thrust (MZT) in an 
area of lower topography related surrounding area. They explain this thickening by overthrusting of the Arabia margin crust by the crust of central Iran along the Main Zagros Recent Faults (MZRF). Recently, Paul et al. [2010] obtained depths of around $53 \mathrm{~km}$ near our profiles I and II. Manaman and Shomali [2010] and Manaman et al. [2011] propose a maximum $65 \mathrm{~km}$ depth for the Zagros region on the same profile as Paul et al. [2006], but their maximum crustal thickness is some $50 \mathrm{~km}$ further SW.

[9] Fewer data exist regarding the lithosphere-asthenosphere boundary (LAB) in the area. Global studies [Hafkenscheid et al., 2006; Priestley and McKenzie, 2006] suggest a strong uplift underneath the Zagros from the Arabian toward the Iranian lithosphere, while a more local study by Kaviani et al. [2007] suggests the position of this lithospheric thinning some 100-150 km NE of the MZT. We expect thus to shed new light on the Moho and LAB depths.

\subsection{Central Iran}

[10] Central Iran covers a roughly triangular area between the Cretaceous-Tertiary Urumieh-Dokhtar magmatic arc [e.g., Omrani et al., 2008] of the Zagros chain and the Alborz. It is a composite area including several blocks detached from Gondwana in Late Paleozoic, accreted to Eurasia in Mesozoic and inducing Cimmerian collisional events (see Zanchi et al. [2009a, 2009b, and references therein] for discussion). In contrast to the surrounding areas, the western part of central Iran is covered by presently subsiding basins. It is largely aseismic and therefore considered to behave as a rigid block [Allen et al., 2004; Guest et al., 2007; Jackson et al., 1995]. Paul et al. [2006, 2010] studied two receiver function profiles crossing central Iran that show both $\sim 42 \mathrm{~km}$ thickness for the crust. Dehghani and Makris [1984] proposed a crustal thickness of 40 $45 \mathrm{~km}$ for central Iran, whereas Sodoudi et al. [2009] found a depth of $47 \mathrm{~km}$ for the Moho using receiver functions.

\subsection{Alborz Mountains}

[11] The Alborz Mountains are a still active collisional belt with $3-5 \mathrm{~km}$ topography, a length of $600 \mathrm{~km}$ in roughly $\mathrm{E}-\mathrm{W}$ direction and a width of $100 \mathrm{~km}$ in N-S direction. It is surrounded by the Talesh Mountains in the west, Binalud and Kopet-Dagh mountains in the east, South Caspian Basin in the north and central Iran in the south. Its basement (including Paleozoic sediments) is covered by up to $3 \mathrm{~km}$ of Mesozoic sediments, $1-2 \mathrm{~km}$ of Cenozoic mostly synorogenic sediments and displayed volcanic activity throughout the Cenozoic, starting in Late Cretaceous [Alavi, 1996]. Volcanism is still sub-active as demonstrated by the quaternary activities around the highest mountain of the Alborz chain, the Damavand volcano. Tectonic activity in this belt is controlled by two different kinds of relative motions [Ritz et al., 2006]: First, the northward convergence of central Iran toward Eurasia (5 mm/yr [Vernant et al., 2004a]) leads to a generally compressive system since about $7 \mathrm{Ma}$. Second, the northwestward motion of the South Caspian Basin with respect to Eurasia resulted in a sinistral transpressional regime in the Alborz $(4 \mathrm{~mm} / \mathrm{yr}$ left-lateral shear [Vernant et al., 2004a]). Since middle Pleistocene, however, the tectonic regime in the central Alborz seems to be changing to transtensional due to an acceleration of the northwest- ward movement of the South Caspian block [Masson et al., 2006; Ritz et al., 2006].

[12] Previous studies have described the crustal structure in the Alborz Mountains, and reported different values for the Moho depth in Central Alborz. Asudeh [1982] based on surface and body waves suggested $45 \mathrm{~km}$ thickness for Moho depth in the west of Alborz. Dehghani and Makris [1984] proposed a crustal thickness of less than $35 \mathrm{~km}$ for Central Alborz based on a gravity study. They also suggested that the Alborz range is isostatically under-compensated at Moho level and no crustal root exists. The chain would be caused by overthrusted nappes in an allochtonous position supported elastically by the lithosphere. Guest et al. [2007] tried to explain the absence of a root under the Alborz by simple crustal folding that caused uplift for the Alborz Mountains and subsidence in the South Caspian Basin and central Iran.

[13] Tatar [2001] studied the crustal thickness and seismicity in the west of Alborz and suggested a $36 \mathrm{~km}$ thick crust. Ashtari et al. [2005] studied the microseismicity of Tehran region and found a Moho depth of $34 \mathrm{~km}$. Doloei and Roberts [2003] modeled a Moho depth under Tehran region of about $46 \mathrm{~km}$. Radjaee et al. [2007] using receiver functions from a temporary seismic network, obtained a crustal thickness of $46-48 \mathrm{~km}$ in the south of Alborz, $55 \mathrm{~km}$ in its central part and about $44 \mathrm{~km}$ in the north of Alborz. This study contradicts the earlier studies, because it presents evidence for a crustal root under the Alborz Mountains. Radjaee et al. [2010] propose that the central Alborz Mountains chain has a moderate crustal root but of insufficient thickness to compensate the elevation of the range. Sodoudi et al. [2009], based on a smaller database than the study of Radjaee et al. [2010], do not see evidence for a crustal root beneath the Alborz; however, their results show 47-54 km depth for the Moho in central Iran and for one single station in the Central Alborz a depth of up to $67 \mathrm{~km}$ which these authors do not consider to be trustworthy. It seems, therefore, that although much work has been done in northern Iran, the crustal structure remains very uncertain.

\subsection{South Caspian Basin and Adjacent Areas}

[14] The South Caspian Basin includes the South Caspian Sea and stretches out onshore west and east in Azerbaijan and Turkmenistan. Sedimentary thickness may reach 20 $25 \mathrm{~km}$ in some parts of the South Caspian Sea [e.g., Glumov et al., 2004]. Pliocene-Quaternary sediments are about $10 \mathrm{~km}$ thick fed by erosion of the surrounding Caucasus, Alborz and Kopet-Dagh orogens and the Russian Platform (sediments brought from the north by the PaleoVolga). Knapp et al. [2004], based on deep seismic reflection, report in the northern part of the South Caspian Basin near the Apsheron-Balkan Sill a very thick (26-28 km) sedimentary cover and a $\sim 10 \mathrm{~km}$ thick crystalline crust with high velocities [e.g., Mangino and Priestley, 1998] often interpreted as having an oceanic affinity [Berberian, 1983; Brunet et al., 2003; Egan et al., 2009; Granath et al., 2007; Green et al., 2009; Knapp et al., 2004; Mamedov, 2004; Zonenshain and Le Pichon, 1986]. Active seismicity in the Apsheron-Balkan Sill [e.g., Allen et al., 2003; Jackson et al., 2002] and deepening of the Moho from south to north are interpreted as evidence for northward subduction of a south Caspian possibly oceanic lithosphere beneath the 
Central Caspian continental lithosphere [e.g., Egan et al., 2009; Granath et al., 2007; Green et al., 2009; Knapp et al., 2004; Mamedov, 2004].

[15] The Apsheron-Balkan Sill (Figure 1) is known as northern boundary between the South Caspian Basin and the central part of Caspian Sea, having a thicker crust and a thinner sedimentary cover [e.g., Berberian, 1983; Egan et al., 2009; Green et al., 2009] than the southern part. The Apsheron-Balkan Sill also connects the Great Caucasus chain to the Ashgabat fault zone [e.g., Hollingsworth et al., 2008; Lyberis and Manby, 1999] and the Kopet-Dagh Mountains.

[16] The Kopet-Dagh Mountains, forming the border between Iran and Turkmenistan northeast of the Alborz, and north of the Binalud Mountains are the least well known tectonic unit of the study area. They have a Meso-Cenozoic sedimentary cover of $\sim 10 \mathrm{~km}$ that has been folded during the late Alpine orogeny [Brunet et al., 2003; Davoudzadeh and Schmidt, 1984; Maksimov, 1992; Milanovsky, 1991; Zamani et al., 2008; Zonenshain et al., 1990].

\subsection{Turan Platform}

[17] The last part of all our three profiles finishes in the southern part of Turan Platform, east of the Caspian Sea. The transition between the Turan platform east of the Caspian Sea and the Scythian platform [Nikishin et al., 1998a, 1998b; Saintot et al., 2006] west of it is not well defined and is probably located offshore. The Turan Platform accreted to Eurasia in Late Paleozoic [e.g., Garzanti and Gaetani, 2002; Thomas et al., 1999]. It has been affected in the Late Triassic (up to the beginning of the Jurassic according to some authors) by the collision (the so-called Eocimmerian orogeny) of the Gondwanian blocks with its southern margin, after partial closure of the Paleotethys Ocean [Belov, 1981; Maksimov, 1992; Milanovsky, 1991; Nikishin et al., 1998a, 2001, 1998b; Sengör et al., 1984; Thomas et al., 1999; Zanchi et al., 2009b]. A weaker compressional event is reported in the Late Jurassic-Early Cretaceous [Nikishin et al., 2001; Thomas et al., 1999]. Thereafter in Cenozoic, the southern parts of this platform became the foreland area of the Kopet-Dagh orogen. The crustal thickness increases gradually from the central part of the South Caspian Basin toward Turkmenistan [Artyushkov, 2007]. Deep seismic sounding profiles by Yegorkin and Matushkin [1970] show a Moho depth of 40-45 km in this part of the Turan Platform.

\section{Method}

[18] We calculate a 2D forward model of the density and temperature distributions beneath the targeted area based on combined interpretation of four data sets. As there aren't any direct measurements of deep density and temperature distributions, the use of single methods like gravity or geothermal interpretation does not yield a unique solution. Therefore, we try to reduce uncertainty by using a set of gravity, geoid and topography data sets that all depend on density distribution but with different distance dependence [Zeyen and Fernàndez, 1994; Zeyen et al., 2005]. Gravity anomalies decrease proportionally to the squared distance (r) from an object, geoid undulations diminish proportionally to $r^{-1}$, whereas topography reflects the average density of the lithosphere which is supposed to be in isostatic equilibrium with respect to the underlying asthenosphere. Therefore, the gravity data is mostly affected by crustal density distribution whereas geoid data are also very sensitive to lower lithospheric density variations. The assumption of local isostasy for topography calculation is assumed to be valid for long wavelengths (above 100-200 km [Turcotte and Schubert, 1982]), especially in areas where the lithosphere is not very thick as in most of Iran. Shorter wavelengths may be supported elastically. The mantle densities are supposed to be linearly dependent on temperature which itself depends on the distribution of radioactive heat production and thermal conductivity within the lithosphere and on the lithospheric thickness. The limit between lithosphere and asthenosphere (LAB) is defined here as the $1300^{\circ} \mathrm{C}$ isotherm.

[19] Modeling is done through trial and error, defining a lithospheric structural model, assigning the physical properties (density, thermal conductivity and heat production) to each body and calculating the effect of this lithospheric model. First, the steady state temperature distribution is calculated using a finite element code that solves the following equation:

$$
\nabla(\mathrm{k}(\mathrm{x}, \mathrm{z}) \nabla \mathrm{T}(\mathrm{x}, \mathrm{z}))+\mathrm{A}(\mathrm{x}, \mathrm{z})=0
$$

where $\mathrm{k}$ is the thermal conductivity, $\mathrm{T}$ the temperature, $\mathrm{A}$ the volumetric heat production and $\nabla$ the 2D gradient operator. Boundary conditions are fixed temperature at the Earth's surface coinciding with the topography $\left(0^{\circ} \mathrm{C}\right)$ and at the $\operatorname{LAB}\left(1300^{\circ} \mathrm{C}\right)$ and no horizontal heat flow across the vertical lateral boundaries of the model. Based on the resulting temperatures and the given reference densities of each body, in situ densities $\rho(\mathrm{T})$ are calculated as

$$
\rho(T)=\rho_{0}\left(1-\alpha\left(\mathrm{T}-\mathrm{T}_{0}\right)\right)
$$

where $\rho_{0}$ is the reference density given for temperature $\mathrm{T}_{0}$ and $\alpha$ is the thermal expansion coefficient $\left(3.5 \times 10^{-5} \mathrm{~K}^{-1}\right.$ [e.g., Afonso et al., 2005]). We make the assumption that in thick sedimentary basins (mainly in the South Caspian Basin), the density depends exponentially on depth. Talwani et al.'s [1959] formula is then used to calculate the 2D gravity effect of a lithospheric model and Chapman's [1979] formula for modeling the geoid anomaly. Topography $\varepsilon$ is calculated in local isostatic equilibrium on $1 \mathrm{D}$ columns as

$$
\varepsilon=\mathrm{H}-\frac{\int \rho(\mathrm{z}) \mathrm{dz}}{\rho_{\mathrm{a}}}+\varepsilon_{0}
$$

where $\mathrm{H}$ is the total lithospheric thickness, including topography, $\rho_{\mathrm{a}}$ is the density of the asthenosphere $(3200 \mathrm{~kg} /$ $\left.\mathrm{m}^{3}\right)$ and $\varepsilon_{0}(-2340 \mathrm{~m})$ is a calibration coefficient that corresponds to the depth of a hypothetical free asthenosphere with respect to sea level [Lachenbruch and Morgan, 1990]. If the resulting topography has a negative value, it is supposed that the corresponding basin is filled with seawater, so that the bathymetry is increased as

$$
\varepsilon_{-}=\varepsilon \frac{\rho_{\mathrm{a}}}{\rho_{\mathrm{a}}-\rho_{\text {fill }}}
$$


Table 1. Rheological Properties of the Different Layers ${ }^{\mathrm{a}}$

\begin{tabular}{llll}
\hline \multicolumn{1}{c}{ Layer } & \multicolumn{1}{c}{$\mathrm{A}$} & $\mathrm{n}$ & $\mathrm{AE}$ \\
\hline Sediments, upper and middle crust & $3.16 \times 10^{-26}$ & 3.3 & 186.5 \\
Lower crust & $6.31 \times 10^{-20}$ & 3.05 & 276 \\
Mantle & $7.0 \times 10^{-14}$ & 3.0 & 510 \\
\hline
\end{tabular}

${ }^{\mathrm{a}}$ Okaya et al. [1996]; A, normalization factor $\left(\mathrm{Pa}^{-\mathrm{n}} \mathrm{s}^{-1}\right) ; \mathrm{n}$, exponent; $\mathrm{AE}$, activation energy $(\mathrm{kJ} / \mathrm{Mol})$.

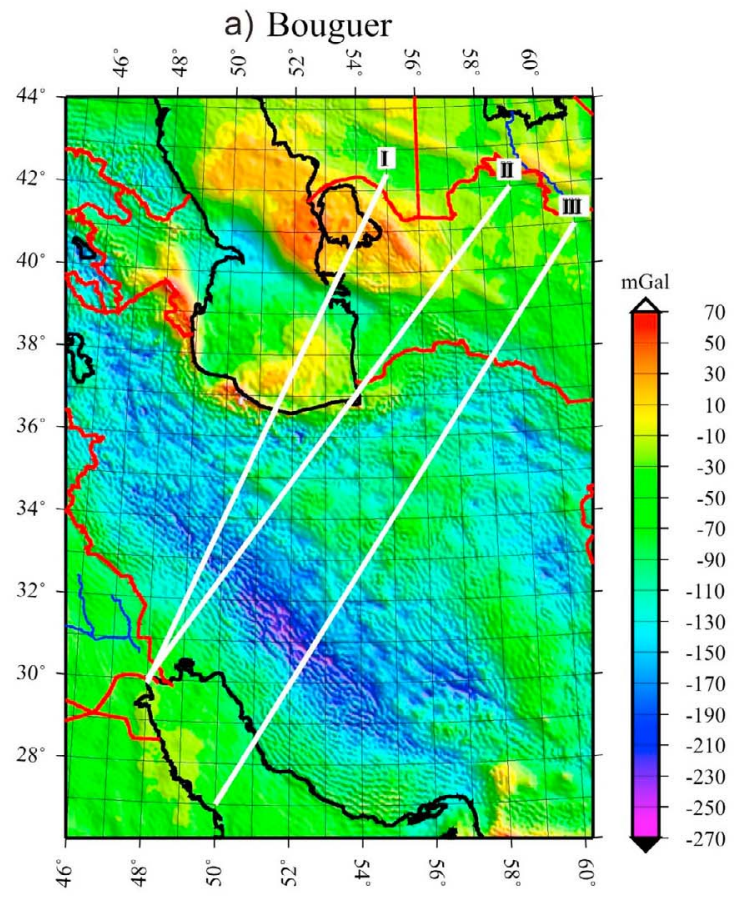

c) Geoid

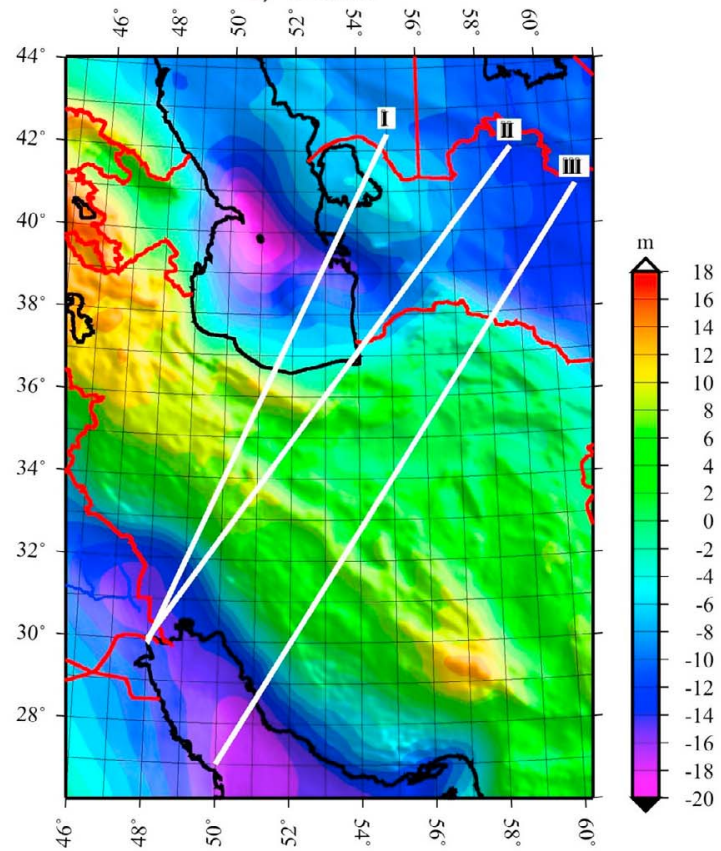

where $\rho_{\text {fill }}$ is the density of the basin infill, here the one of seawater $\left(1030 \mathrm{~kg} / \mathrm{m}^{3}\right)$.

[20] During modeling, it is not always possible to fit all data at the same time; some hierarchy has to be established. As can be seen mainly on Figure 3, surface heat flow data present normally strong dispersion, which is generally due to near-surface effects like groundwater flow. In addition, we usually do not have any information on vertical distri-

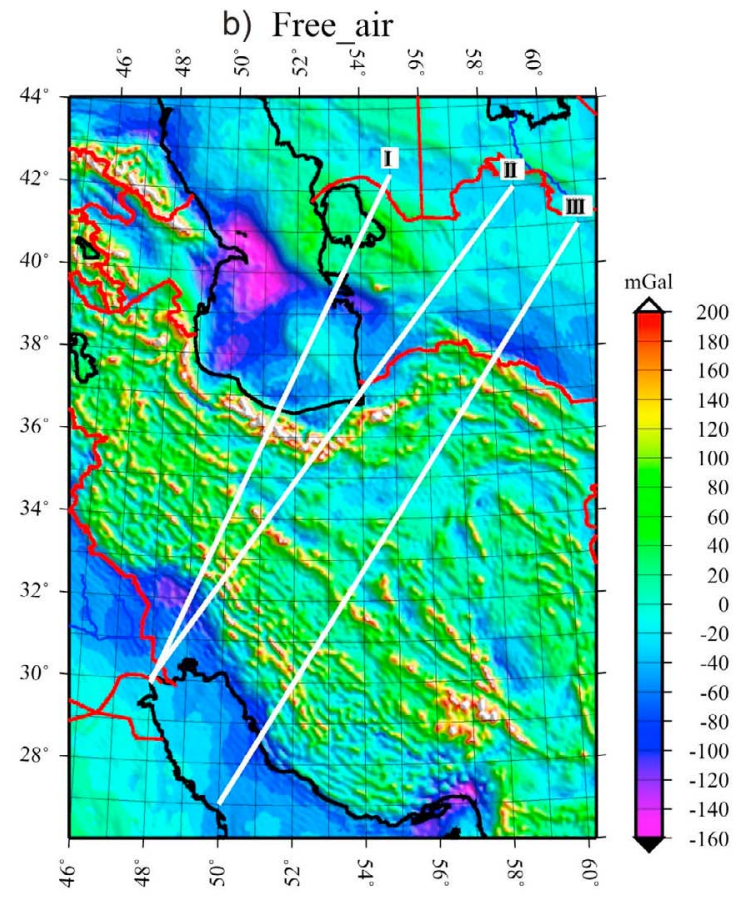

d) Heat flow

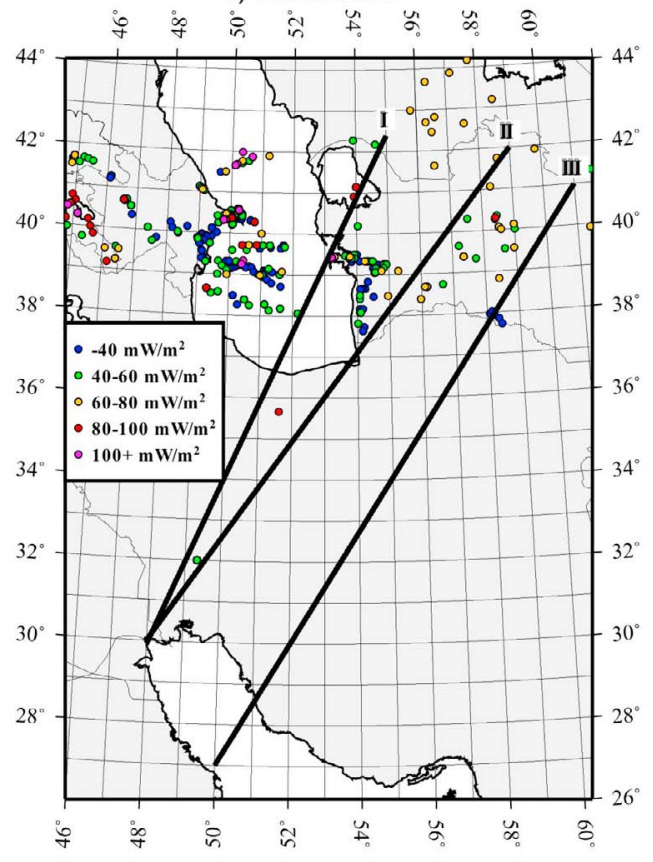

Figure 2. Data and interpreted profiles: (a) Bouguer anomalies, (b) free air gravity anomalies (both from BGI: http://bgi.omp.obs-mip.fr), (c) geoid undulations with spherical harmonics up to degree and order 10 removed (EGM2008 [Pavlis et al., 2008]), (d) heat flow data [Pollack et al., 1993]. 
Profile I: Iran-Caspian $\left(48^{\circ} \mathrm{E} / 29.9^{\circ} \mathrm{N}-55^{\circ} \mathrm{E} / 42.4^{\circ} \mathrm{N}\right)$

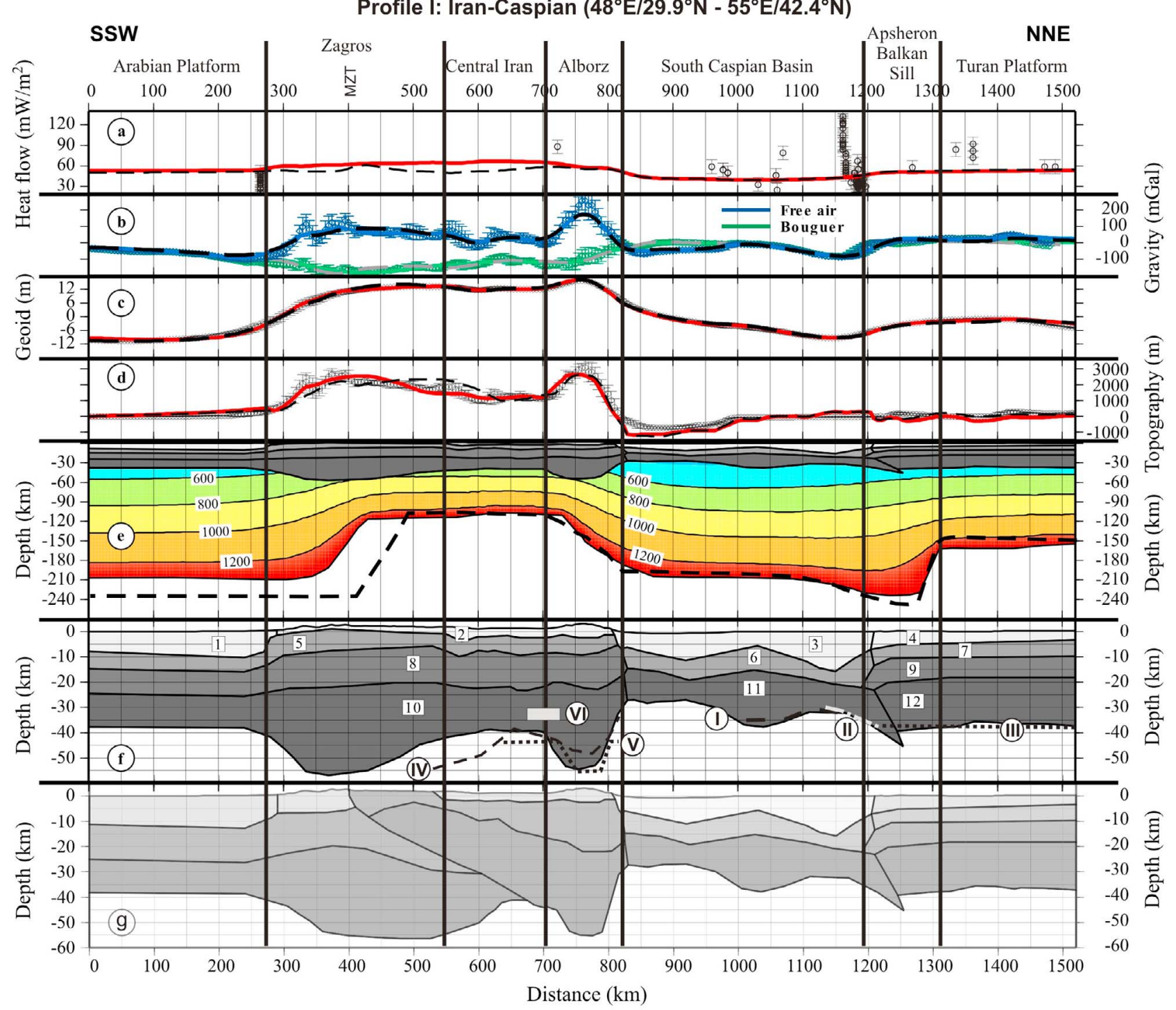

Figure 3. Modeling results of profile I. In Figures 3a-3d, continuous lines correspond to modeling results, dots with uncertainty bars correspond to measured data. Dashed lines correspond to results of model Paul_2 (Figure 3g). In Figure 3b, blue line and symbols corresponds to free air gravity anomalies, green ones to Bouguer anomalies. The lithospheric model is presented in Figure $3 \mathrm{e}$ with equal horizontal and vertical scales (dashed line shows the LAB of a model using the crust of Paul_2). The crustal bodies are shaded gray. In the mantle, the temperature distribution is plotted with isotherms every $200^{\circ} \mathrm{C}$. The lowermost line corresponds to the $1300^{\circ} \mathrm{C}$ isotherm, interpreted as base of the lithosphere. Figure $3 \mathrm{f}$ shows a blow-up of the crustal structure of our preferred model, Figure $3 \mathrm{~g}$ shows the model Paul 2 (see discussion). The numbering of the bodies corresponds to the numbers in Table 1. Roman numbers and related dashed or dotted lines indicate Moho depths from different seismic models: I, Artyushkov [2007]; II, Knapp et al. [2004]; III, Yegorkin and Matushkin [1970]; IV, Paul et al. [2010];V, Radjaee et al. [2010]; VI, Ashtari et al. [2005].

bution of heat production, which is thus to some degree a free parameter that helps explaining the surface heat flow, hardly affecting the other parameters. Therefore, these data are treated as merely indicative. The assumption of local isostatic equilibrium imposes a strong constraint on topography inversion. Therefore, in case of incompatibility between these data and gravity and geoid, preference is given to a good fit of gravity and geoid data.
[21] Based on the temperature and pressure distribution resulting from the model, we calculate the brittle and ductile strength distribution, where strength is defined as differential stress $\Delta \sigma$ necessary to deform a rock. Following Anderson's theory of faulting, the brittle strength, is assumed to increase linearly with pressure [Turcotte and Schubert, 1982]:

$$
\Delta \sigma=\frac{ \pm 2 \mathrm{fP}_{\text {eff }}}{\sqrt{1+\mathrm{f}^{2}} \mp \mathrm{f}}
$$




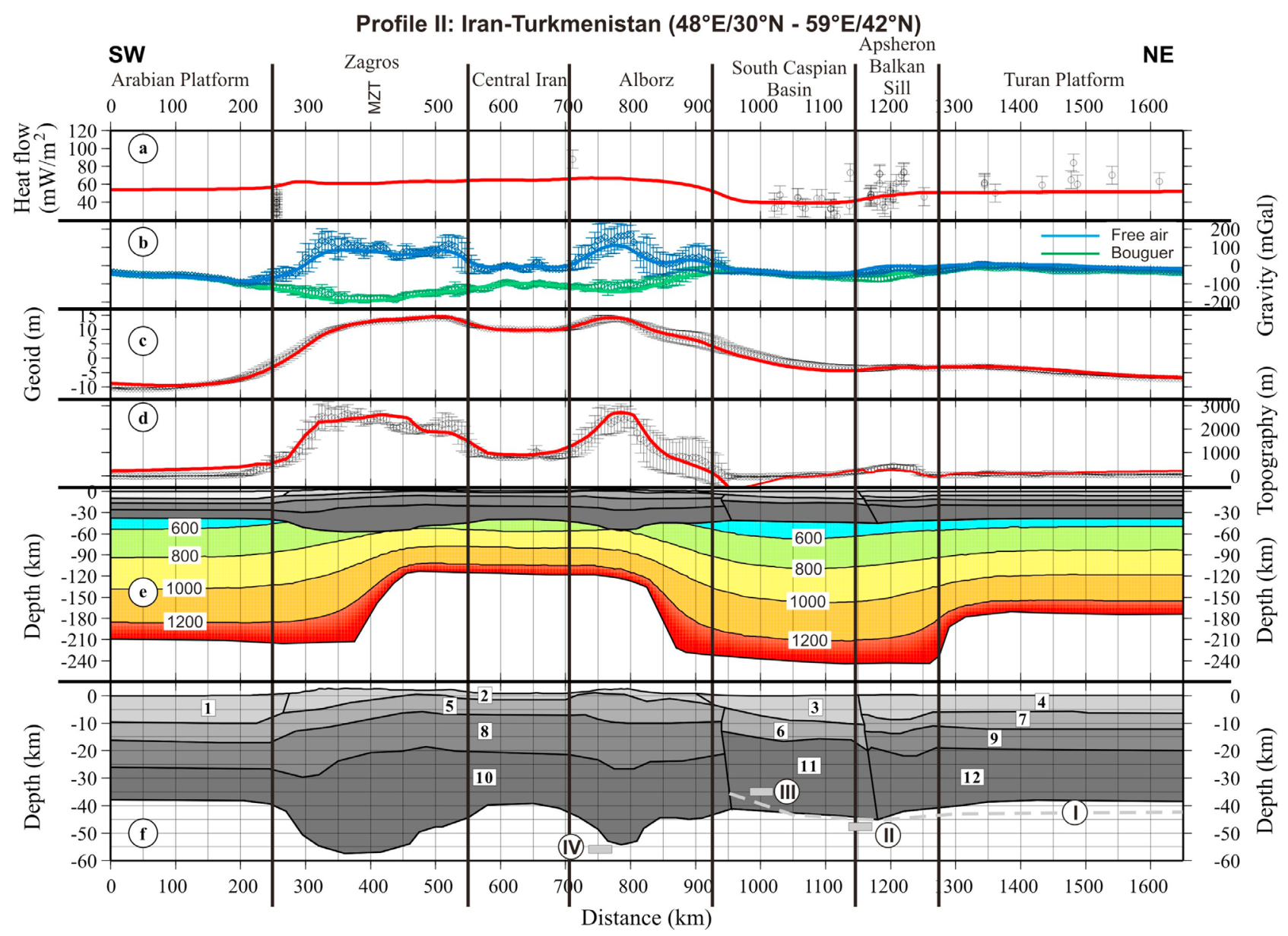

Figure 4. Modeling results of profile II. In Figures $4 \mathrm{a}-4 \mathrm{~d}$, continuous lines correspond to modeling results, dots with uncertainty bars correspond to measured data. In Figure 4b, blue line and symbols corresponds to free air gravity anomalies, green ones to Bouguer anomalies. The lithospheric model is presented in Figure $4 \mathrm{e}$ with equal horizontal and vertical scales. The crustal bodies are gray-shaded. In the mantle, the temperature distribution is plotted with isotherms every $200^{\circ} \mathrm{C}$. The lowermost line corresponds to the $1300^{\circ} \mathrm{C}$ isotherm, interpreted as base of the lithosphere. Figure $4 \mathrm{f}$ shows a blow-up of the crustal structure. The numbering of the bodies corresponds to the numbers in Table 1. Roman numbers and related dashed or dotted lines indicate Moho depths from different seismic models: I, Yegorkin and Matushkin [1970]; II, Jackson et al. [2002]; III, Mangino and Priestley [1998]; IV, Abbassi et al. [2010].

where the upper sign is for compressional, the lower one for extensional strength, $\mathrm{f}$ is the friction coefficient assumed to be 0.7 and $P_{\text {eff }}$ is the effective pressure calculated as

$$
\mathrm{P}_{e f f}=g \int(\rho(z) d z)-P_{w}
$$

$\mathrm{g}$ being Earth's gravity $\left(9.81 \mathrm{~m} \mathrm{~s}^{-2}\right), \mathrm{P}_{\mathrm{w}}$ the water pressure, taken as hydrostatic in the upper crust and zero in the lower crust and upper mantle.

[22] For modeling the ductile strength dislocation slip has been used [Turcotte and Schubert, 1982]:

$$
\sigma(T)=\left(\frac{\dot{\varepsilon}}{A}\right)^{\frac{1}{n}} \exp \left(\frac{A E}{n R T}\right)
$$

Explanation and values of the parameters for the different layers are given in Table 1. The strength distribution, when integrated along vertical lithospheric columns, allows to compare the resistance of the whole lithosphere to stress in different areas.

\section{Data}

[23] The data we used come mainly from global data sets. Topography data (Figure 1) are taken from 1-min TOPEX global data sets [Sandwell and Smith, 1997, 2009; ftp:// topex.ucsd.edu/pub]. Free air and Bouguer gravity data (Figures $2 \mathrm{a}$ and $2 \mathrm{~b}$ ) are 2.5 arc-minute by 2.5 arc-minute grid are taken from the database of Bureau Gravimétrique International (BGI, http://bgi.omp.obs-mip.fr). Geoid height variations (Figure 2c) correspond to the EGM2008 model [Pavlis et al., 2008]. In order to avoid effects of sublithospheric density variations on the geoid, we have removed the geoid signature corresponding to the EGM2008 spherical harmonics developed until degree and order 10 [Bowin, 


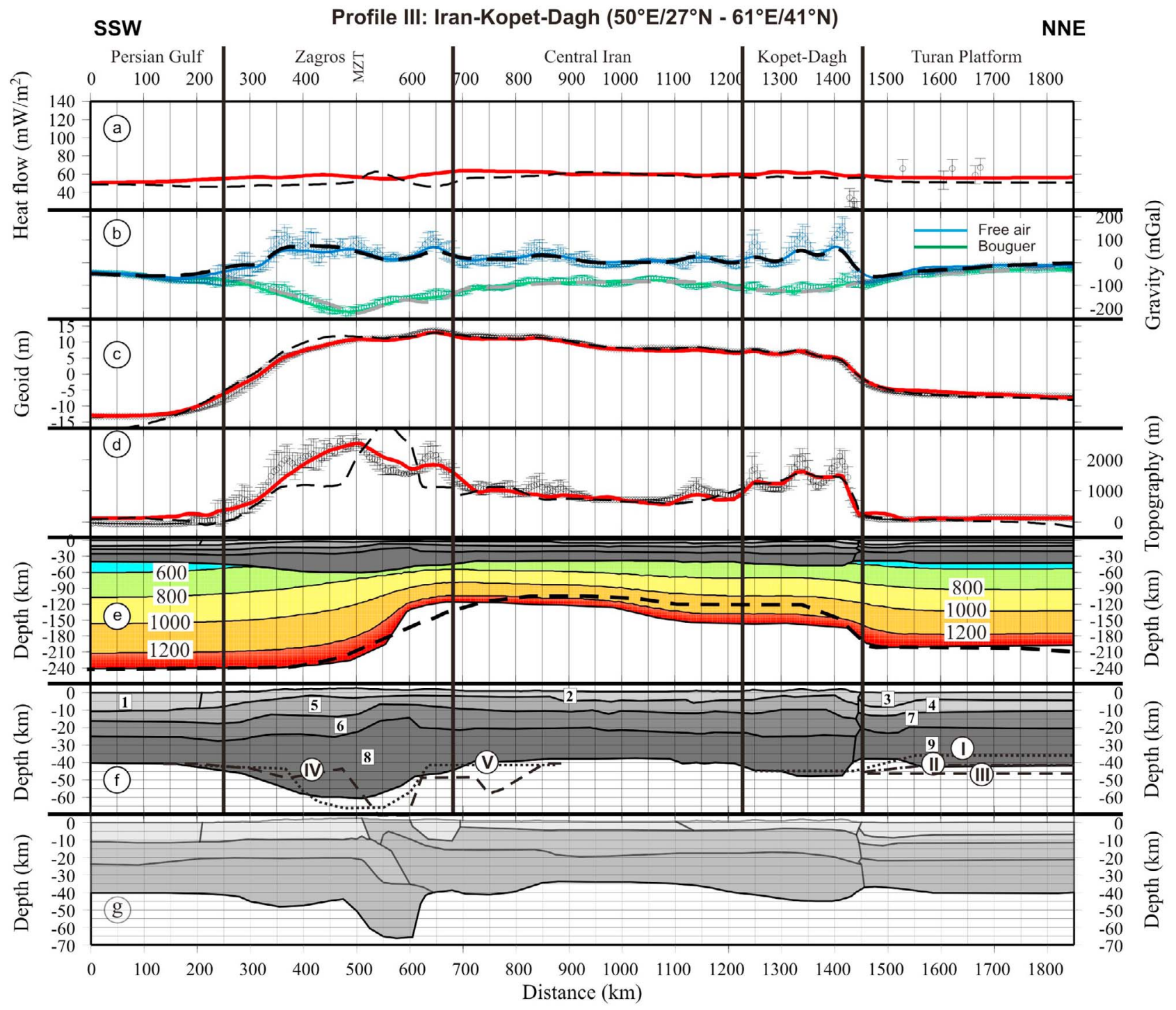

Figure 5. Modeling results of profile III. In Figures 5a-5d, continuous lines correspond to modeling results, dots with uncertainty bars correspond to measured data. Dashed lines correspond to results of model Paul_1 (Figure 3g). In Figure 5b, blue line and symbols corresponds to free air gravity anomalies, green ones to Bouguer anomalies. The lithospheric model is presented in Figure 5e with equal horizontal and vertical scales (dashed line shows the LAB of a model using the crust of Paul_1). The crustal bodies are gray-shaded. In the mantle, the temperature distribution is plotted with isotherms every $200^{\circ} \mathrm{C}$. The lowermost line corresponds to the $1300^{\circ} \mathrm{C}$ isotherm, interpreted as base of the lithosphere. Figure $5 \mathrm{f}$ shows a blow-up of the crustal structure. Figure 5g shows the model Paul_1 (see discussion). The numbering of the bodies corresponds to the numbers in Table 1. Roman numbers and related dashed or dotted lines indicate Moho depths from different seismic models: I, Mooney [1999]; II and III, -range of values given by Yegorkin and Matushkin [1970]; IV, Paul et al. [2006]; V, Manaman and Shomali [2010].

1991; Lemoine et al., 1998]. The few available heat flow data (Figure 2d) come from Pollack et al. [1993]. In order to take into account the variability of the geoid, free air, Bouguer and topography data in the direction perpendicular to the profiles and to avoid interpreting extreme features being located incidentally on the profile, we averaged the data within a stripe of $50 \mathrm{~km}$ width to both sides of the profiles and calculated the variance within this stripe for $5 \mathrm{~km}$ long steps along the profiles. The resulting standard deviation is plotted in Figures $3-5$ as uncertainty bars.

\section{Modeling Results}

[24] As the structural domains concerned in this paper were mainly created under the effect of the NNE-SSW convergence of the Arabian Plate with Eurasia [Guest et al., 
2007; Vernant, 2003; Vernant and Chery, 2006], most of these structures are approximately perpendicular to this direction (Figure 1). Therefore, in order to avoid as much as possible effects of three dimensional structures in our 2D modeling, we chose the profiles perpendicular to the strike roughly in NNE-SSW direction.

[25] The lateral resolution of our data is of the order of several kilometers. Therefore, we cannot reproduce smallscale details. Our models consist of a sedimentary layer, the upper, middle and lower crust and a lithospheric mantle layer. In order to constrain the various thicknesses, the results of previous works carried out in this area were used [Alekseev et al., 1973; Artyushkov, 2007; Dehghani and Makris, 1984; Glumov et al., 2004; Guest et al., 2007; Knapp et al., 2004; Mangino and Priestley, 1998; Molinaro et al., 2005b; Paul et al., 2006; Paul et al., 2010; Radjaee et al., 2007; Sodoudi et al., 2009; Yegorkin and Matushkin, 1970]. The data adjustment of the three profiles is shown in Table 3.

\subsection{Profile I}

[26] Profile I with a length of about $1500 \mathrm{~km}$ starts from a point near the NW end of the Persian Gulf and crosses the Zagros, central Iran, Alborz, South Caspian Basin and Apsheron-Balkan Sill (Figure 1). The model for this profile is presented in Figure 3. The crust-mantle boundary (Moho) is located at a depth of $37-38 \mathrm{~km}$ under the Arabian Plate. When entering the Zagros Fold and Thrust Belt and with increasing topography the Moho deepens to a maximum of $\sim 56 \mathrm{~km}$ beneath MZT. Further north, the Moho depth gradually decreases to a minimum of $39 \mathrm{~km}$ under central Iran. At the southern border of the Alborz it deepens again with a noticeable slope up to a maximum of $55 \mathrm{~km}$ underneath the Central Alborz which is an evidence for the existence of a root underneath the Alborz Mountains in contrast to some previous work where these mountains were considered to be rootless [Dehghani and Makris, 1984; Sodoudi et al., 2009].

[27] When entering the South Caspian Basin, the crustal structure changes completely. Near the coast, the Moho rises up to about $27 \mathrm{~km}$ whereas the sedimentary layer thickens to $15 \mathrm{~km}$ of which about $7 \mathrm{~km}$ are Tertiary sediments and the remaining $8 \mathrm{~km}$ Mesozoic ones. The Tertiary sediments were modeled with an exponential density increase from 2200 to $2750 \mathrm{~kg} / \mathrm{m}^{3}$, whereas the Mesozoic sediments, given their deep burial, were modeled with a constant density of $2750 \mathrm{~kg} / \mathrm{m}^{3}$ (see Table 2 for the physical properties used in the different layers). Toward the north, the sediments thicken to $19 \mathrm{~km}$. In the southern part of the South Caspian Basin, the thin crystalline crust indicates a possible oceanic character or a highly thinned continental crust, keeping only the lower high density part of the crust. The nature of this crust is hypothetical (see the discussions, e.g., by Mangino and Priestley [1998] and Brunet et al. [2003]). There are no magnetic anomalies in the South Caspian Basin and the crustal as well as lithospheric thicknesses are larger than for normal oceanic lithosphere. Nevertheless, this crust was created probably in the Jurassic, a quiet period for magnetic anomalies; oceanic crust may be thicker than normal due to intrusions. The South Caspian Basin has a limited extent and was possibly created as backarc basin without having a well established mid-oceanic ridge. Since the Jurassic, it has cooled a lot, so that a thickened lithosphere is no irrefutable evidence for continental nature. It could be that in a small basin such as the south Caspian one, the small-scale convection supposed to limit the thickness of normal oceanic lithosphere cannot act efficiently. In the central South Caspian Basin, the Moho descends to $37 \mathrm{~km}$ depth whereas the sediments thin to $15 \mathrm{~km}$, resulting in a strong thickening of the crystalline crust in this area. Further north, the Moho deepens to up to $45 \mathrm{~km}$, roughly paralleled by the base of the sediments that descends to about $23 \mathrm{~km}$ in the area of the ApsheronBalkan Sill. This thickening of the crust is compatible with a model of subduction of South Caspian crust underneath the Apsheron-Balkan Sill and the continental crust of the Central Caspian [Knapp et al., 2004]. Finally at the end of profile I, on the Turan Platform, we find the Moho at 35$37 \mathrm{~km}$ depth.

[28] The lithospheric thickness varies from 200 to $210 \mathrm{~km}$ below the Arabian Platform and the South Caspian Basin to about $110 \mathrm{~km}$ underneath central Iran. The thin lithosphere starts shortly NE of the MZT and it thickens again at the southern limit of the Alborz Mountains. Similar results, although at varying distance from the MZT, have been reported by Molinaro et al. [2005b], Hafkenscheid et al. [2006], Kaviani et al. [2007], Paul et al. [2010] and Manaman and Shomali [2010]. Some authors such as Molinaro et al. [2005b] and Manaman and Shomali [2010] interpreted the thinning as slab break off. Beneath the South Caspian Basin, the lithosphere thickens slowly toward the Apsheron-Balkan Sill up to a maximum of nearly $240 \mathrm{~km}$. Further north, we model a strong thinning to about $150 \mathrm{~km}$ under the western part of the Turan Platform. This structure, as well as the crustal thickness variations, point toward a subduction of the South Caspian block toward the N-NW.

\subsection{Profiles II and III}

[29] Honoring the constraints imposed on sedimentary and crustal thicknesses, the main problem in our modeling was to fit the topography data on the part of profile I crossing the South Caspian Sea. Therefore, we modeled a second profile. Profile II is $1650 \mathrm{~km}$ long and starts in the SW from the same point as profile I, but in a more easterly direction in order to avoid crossing the Caspian Sea in the area of very thick sediments. Instead, profile II crosses the transition zone from the easternmost part of the South Caspian Basin to westernmost Kopet-Dagh Mountains (Figure 1). The modeling results for profile II (Figure 4 and Table 2) are generally similar to those of profile I except for the part of the profile between Alborz and Turan Platform. In this area, profile II shows thinner sedimentary layers and a thicker crust than profile I (41 km versus $27 \mathrm{~km}$ just north of the Alborz). Also the evidence for a possible subduction of the South Caspian block toward the north is less clear.

[30] A third profile with $1850 \mathrm{~km}$ length runs parallel to profile I in SW-NE direction and crosses the Persian Gulf, Zagros, central Iran, Kopet-Dagh and finishes on the Turan Platform (Figure 1). For the Persian Gulf zone, we have an average of $\sim 40 \mathrm{~km}$ for crustal thickness which below the Zagros Mountains gradually increases until reaching a maximum of $60 \mathrm{~km}$ underneath the MZT. The thickness of the crust in central Iran is nearly the same as for the other profiles, around $38-39 \mathrm{~km}$. The crust thickens under the 
Table 2. Physical Properties of the Rocks Making Up the Different Bodies in the Models ${ }^{\mathrm{a}}$

\begin{tabular}{|c|c|c|c|c|}
\hline No. & Rock Type & $\mathrm{TC}$ & HP & Density \\
\hline \multicolumn{5}{|c|}{ Profiles I/II } \\
\hline 1 & Sediments Arabian foreland & 2.0 & 1.0 & 2550 \\
\hline 2 & Sediments central Iran, Alborz & 2.0 & 1.0 & 2650 \\
\hline 3 & Cenozoic sediments South Caspian Basin & 2.0 & 1.0 & $2750-550 \exp (-z / 12)($ profile I $) / 2530$ (profile II) \\
\hline 4 & Sediments Turan Platform & 2.0 & 1.0 & 2550 \\
\hline 5 & Upper crust Arabia and Iran & 2.8 & 1.5 & 2800 \\
\hline 6 & Mesozoic sediments South Caspian Basin & 2.5 & 1.0 & 2750 \\
\hline 7 & Upper crust Turan Platform & 2.8 & 1.5 & 2800 \\
\hline 8 & Middle crust Arabia and Iran & 2.8 & 1.5 & 2820 \\
\hline 9 & Middle crust Turan Platform & 2.8 & 2.0 & 2820 \\
\hline 10 & Lower crust Arabia and Iran & 2.2 & 0.2 & 2950 \\
\hline 11 & Oceanic crust South Caspian Basin & 2.2 & 0.2 & 2950 \\
\hline 12 & Lower crust Turan Platform & 2.2 & 0.2 & 2950 \\
\hline & Lithospheric mantle & 3.4 & 0.02 & $3200\left(1+3.5 \times 10^{-5}(1300-\mathrm{T}(\mathrm{z}))\right)$ \\
\hline \multicolumn{5}{|c|}{ Profile III } \\
\hline 1 & Sediments Persian Gulf & 2.0 & 1.0 & 2530 \\
\hline 2 & Sediments central Iran, Alborz & 2.0 & 1.0 & 2650 \\
\hline 3 & Sediments Turan Platform & 2.0 & 1.0 & 2550 \\
\hline 4 & Upper crust Turan Platform & 2.8 & 1.5 & 2800 \\
\hline 5 & Upper crust Arabia and Iran & 2.8 & 1.5 & 2800 \\
\hline 6 & Middle crust Arabia and Iran & 2.8 & 1.5 & 2820 \\
\hline 7 & Middle crust Turan Platform & 2.8 & 2.0 & 2820 \\
\hline 8 & Lower crust Arabia/Iran & 2.2 & 0.2 & 2950 \\
\hline \multirow[t]{2}{*}{9} & Lower crust Turan Platform & 2.2 & 0.2 & 2950 \\
\hline & Lithospheric mantle & 3.4 & 0.02 & $3200\left(1+3.5 \times 10^{-5}(1300-\mathrm{T}(\mathrm{z}))\right)$ \\
\hline
\end{tabular}

${ }^{\mathrm{a}}$ No., number of the body in Figures $3-5$; TC, thermal conductivity $(\mathrm{W} /(\mathrm{m} \mathrm{K}))$; HP, heat production $\left(\mu \mathrm{W} / \mathrm{m}^{3}\right)$; Density $\left(\mathrm{kg} / \mathrm{m}^{3}\right)$; $\mathrm{T}(\mathrm{z})$, temperature as function of depth $\left({ }^{\circ} \mathrm{C}\right)$; $\mathrm{z}$, depth $(\mathrm{km})$.

Kopet-Dagh Mountains till $48 \mathrm{~km}$ and with a strong slope reaches $37 \mathrm{~km}$ underneath the Kopet-Dagh foreland basin. For the rest of the profile in Turan Platform, it is about $42 \mathrm{~km}$ thick. NE of the MZT, we see a strong thinning of the lithosphere to about $110 \mathrm{~km}$. This could be evidence for a slab break off in this area as evidenced also by Manaman and Shomali [2010]. The lithosphere thickens again strongly further north when approaching the Turan Platform.

\section{Discussion}

\subsection{General Considerations and Elastic Support}

[31] The models presented here have two important constraints: steady state thermal modeling and local isostasy. Thermal equilibrium may not be reached in some parts of the profiles. The effect of non-equilibrium would be to increase the lithospheric thickness variations as can be seen when analyzing the possible effects of recent heating of the lithosphere: Since heat transport through the lithosphere is a slow process, this heating would have affected only the base of the lithosphere and leave its upper parts relatively cool and therefore denser. Our models indicate a certain average lithospheric thickness in order to explain the topography. Since we assume thermal equilibrium, we consider that the whole lithosphere has been heated up and therefore we model a slightly less dense lithosphere than in reality. In order to have the needed low density, the lithosphere would then have to be even thinner in reality than in our model. Correspondingly, the opposite would happen for a recent cooling. Therefore, we consider our models to present minimum lateral lithospheric thickness variations.

[32] Regional isostasy (elastic flexure) may support part of the topography. Considering an average equivalent elastic thickness of the lithosphere of $20 \mathrm{~km}$ would imply that wavelengths of less than $200 \mathrm{~km}$ would be affected by flexure. To be meaningful flexure modeling needs knowledge of the detailed history of vertical movements in the different areas of our region which we do not have. Therefore, only wavelengths of more than 100 to $200 \mathrm{~km}$ can be interpreted. Flexural effects are certainly able to explain most of the misfit in the Kopet-Dagh area of profile III and the short-wavelength misfits in the South Caspian Basin. We did some numerical tests based on the assumption of a homogeneous elastic plate, calculating its elastic support of the residual topography differences using spectral analysis. For a given wavelength $\lambda$, the deformation $\omega$ of a plate as function of the amplitude $\mathrm{h}$ of topography is calculated as [Turcotte and Schubert, 1982]:

$$
\omega=\mathrm{h} \frac{\rho_{\mathrm{t}} \mathrm{g}}{\mathrm{D}\left(\frac{2 \pi}{\lambda}\right)^{4}+\left(\rho_{\mathrm{a}}-\rho_{\mathrm{t}}\right) \mathrm{g}}
$$

where $\mathrm{D}$ is the flexural rigidity, $\rho_{\mathrm{t}}$ is the density of topography, $\rho_{\mathrm{a}}$ is that of the asthenosphere and $\mathrm{g}$ is gravity.

[33] On profile III, for a $10 \mathrm{~km}$ thick elastic plate, the overall elastic support of the residual topography along the profile is $32 \%$, for the Kopet-Dagh area, it is $50 \%$. For a $30 \mathrm{~km}$ thick plate, the corresponding values are $50 \%$ versus $70 \%$, for a $50 \mathrm{~km}$ thick plate they are $60 \%$ versus $78 \%$.

[34] Since the algorithm is trial and error, we cannot give numerical uncertainties of our models. After many tests, we nevertheless estimate the uncertainty as $15-20 \%$ of the lithosphere thickness. The models lose resolution for lithosphere thicknesses above about $250 \mathrm{~km}$. We have some trade off between inner crustal structures and crustal thickness, which leads to an uncertainty of crustal thickness of up to $10 \%$ where no seismic constraints are available. How- 

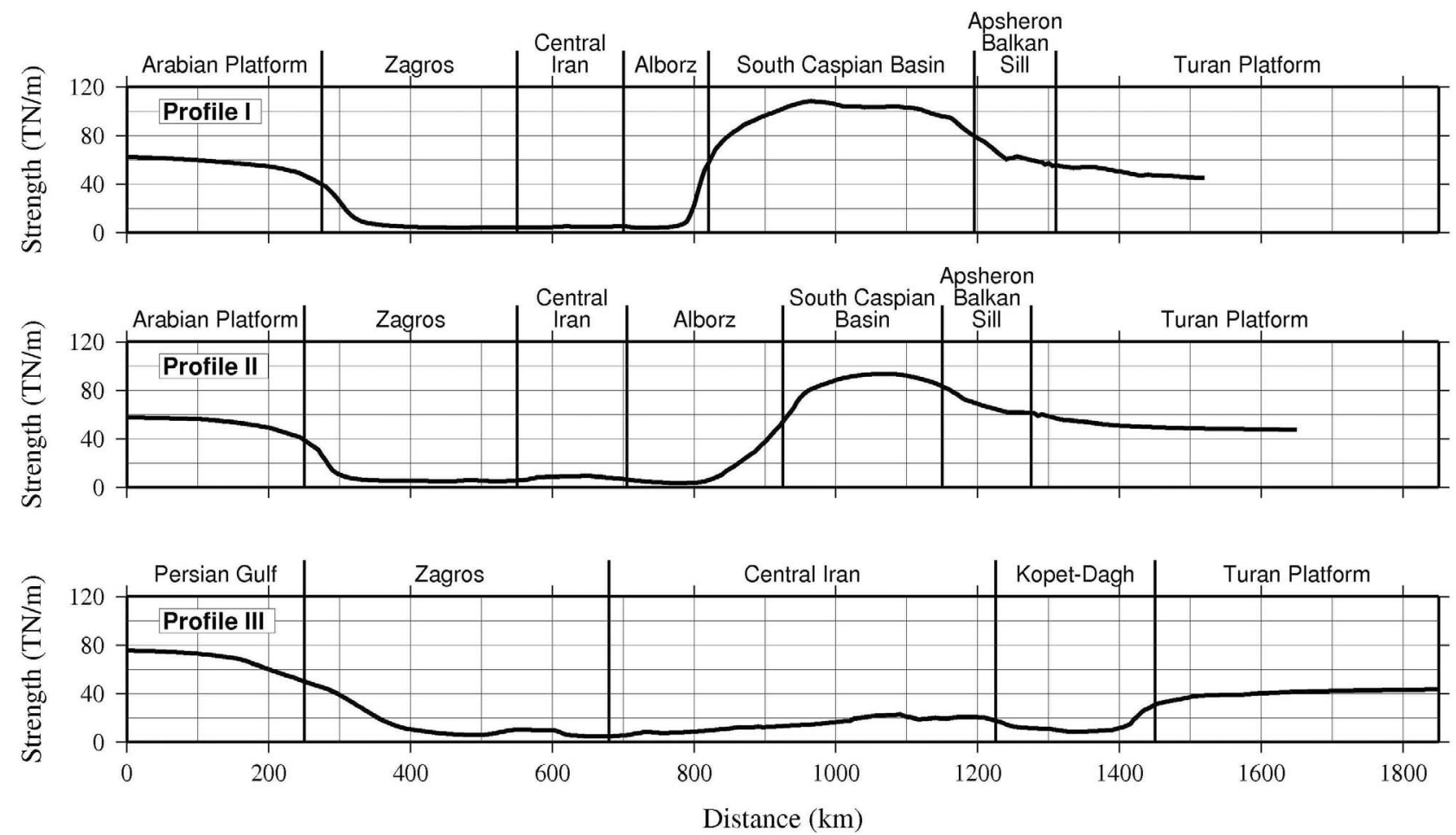

Figure 6. Comparison of the vertically integrated strength of the lithosphere for the three interpreted profiles.

ever, with reasonable geological and density assumptions, we consider this uncertainty to be effectively smaller than this $(5-10 \%)$.

\subsection{Lithosphere and Rheological Considerations}

[35] When looking at the modeling results of the three profiles, thinning of the lithosphere is observed in central Iran. This corresponds well with different images of seismic tomography that show high velocities underneath the Arabian Platform, the South Caspian Basin and the Eurasia Plate but low velocities under central Iran [e.g., Al-Damegh et al., 2004; Alinaghi et al., 2007]. Hafkenscheid et al. [2006] published a tomography cross section that coincides quite well with our profiles I and II. On this cross section, they obtained high velocities until the mantletransition zone under the Persian Gulf and Zagros fold thrust belt (ZFTB) and low velocities from the surface to the base of the upper mantle under central Iran. Also further north, high velocities are interpreted as lithospheric thickening under the South Caspian Basin followed northward by a slight relative thinning under the Turan Platform.

[36] Another interesting feature of the lithosphere base is the vanishing evidence for lithospheric thickening along the northern edge of the South Caspian block southeastward under the Kopet-Dagh. The modeled thickness variations seem to indicate that the thin, high density, either oceanic crust or thinned continental one, is restricted to the South Caspian Sea and narrow surroundings. Here the crust acts as a rigid block that reacts to the continuous convergence between Arabia and Eurasia not by internal deformation but stays relatively undeformed and subducts therefore toward the N-NW. Based on the temperature distribution, we cal- culated the distribution of compressional rock strength along the profiles using the parameters given in Table 1. The vertical integral of this strength allows comparison of the resistance of the whole lithosphere to compressive stresses in different areas. On Figure 6, we observe that on profiles I and II, the strongest lithosphere is found between 800 and $1200 \mathrm{~km}$, corresponding to the South Caspian Basin. At the same distance from the Zagros convergence zone on profile III, the situation is inverted the lithosphere being very weak. This observation could explain why there is subduction underneath the Apsheron-Balkan sill but not under the Kopet-Dagh as we interpreted from our modeling results. The strong South Caspian block acts as relatively rigid block producing on the one hand crustal deformation toward the south in the Alborz Mountains, where Vernant et al. [2004b] give presently a shortening rate of $6-8 \mathrm{~mm} / \mathrm{yr}$. On the other hand, toward the north, the $6-7 \mathrm{~mm} / \mathrm{yr}$ convergence [Vernant et al., 2004b] is accommodated by subduction of this rigid block underneath Eurasia. In the Kopet-Dagh area; however, the overall smaller convergence of $8 \mathrm{~mm} / \mathrm{yr}$ [Vernant et al., 2004b] does not lead to subduction under Eurasia, due to the weakness of the lithosphere. The convergence is partly accommodated by westward escape of the South Caspian block [Hollingsworth et al., 2006], partly by mainly crustal deformation.

\subsection{Crust}

[37] In the South Caspian Basin, Kopet-Dagh and Turan platform some Moho constraints from previous studies [e.g., Artyushkov, 2007; Jackson et al., 2002; Knapp et al., 2004; Mangino and Priestley, 1998; Yegorkin and Matushkin, 1970] are used and shown in Figures 3f, 4f and 5f. We 
Table 3. Misfit Between Measured and Calculated Data $(1 \sigma)$ for the Three Profiles and the Test Models Presented in Figures 3, 4, 5 and $7^{\mathrm{a}}$

\begin{tabular}{lcccc}
\hline \multicolumn{1}{c}{ Profile } & Free Air Gravity (mGal) & Bouguer Anomaly (mGal) & Geoid (m) & Topography (m) \\
\hline I & 14 & 13 & 0.53 & 266 \\
II & 15 & 14 & 0.70 & 207 \\
III & 13 & 10 & 0.58 & 175 \\
I (Crustal model in Zagros from Paul et al. $[2006])$ & 16 & 15 & 0.60 & 303 \\
III (Crustal model in Zagros from Paul et al. $[2010])$ & 16 & 13 & 1.35 & 439 \\
I (Alborz rootless adjusted) & 14 & 13 & 0.79 \\
\hline
\end{tabular}

${ }^{a}$ For the surface heat flow data, the strong local variability and few available data do not allow to give a meaningful misfit value.

kept our models as near as possible to these Moho constraints and discrepancies in this area are within the modeling resolution. Since sedimentary thickness is known in the southernmost South Caspian Basin and gravity data are very sensitive to lateral variations in crustal thickness, we think that also in this area without seismic data, the very thin crust is well constrained.

\section{A Profile I: Alborz Rootless - Not adjusted SSW NNE}

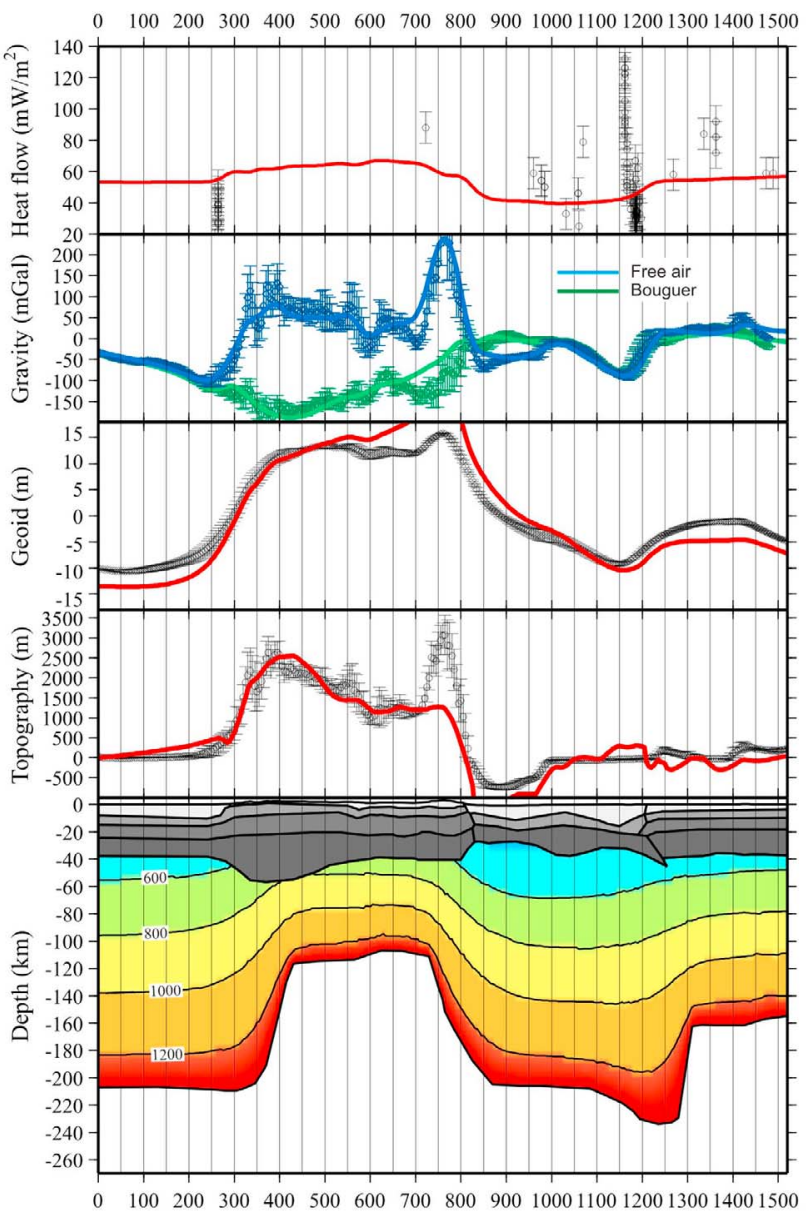

Distance $(\mathrm{km})$
[38] In the Alborz region, however many studies have been done but a large variety of crustal thicknesses (35$67 \mathrm{~km}$ ) have been reported which are mainly due to differences in assumed $v_{p}$ and $v_{s}$ velocities and model resolutions in the receiver function inversions. For more information about the reasons of these big discrepancies in this area, refer to Abbassi et al. [2010] and Radjaee et al. [2010]. Our
NNE

$\begin{array}{lllllllllll}0 & 100 & 200 & 300 & 400 & 500 & 600 & 700 & 800 & 900 & 100011001200130014001500\end{array}$

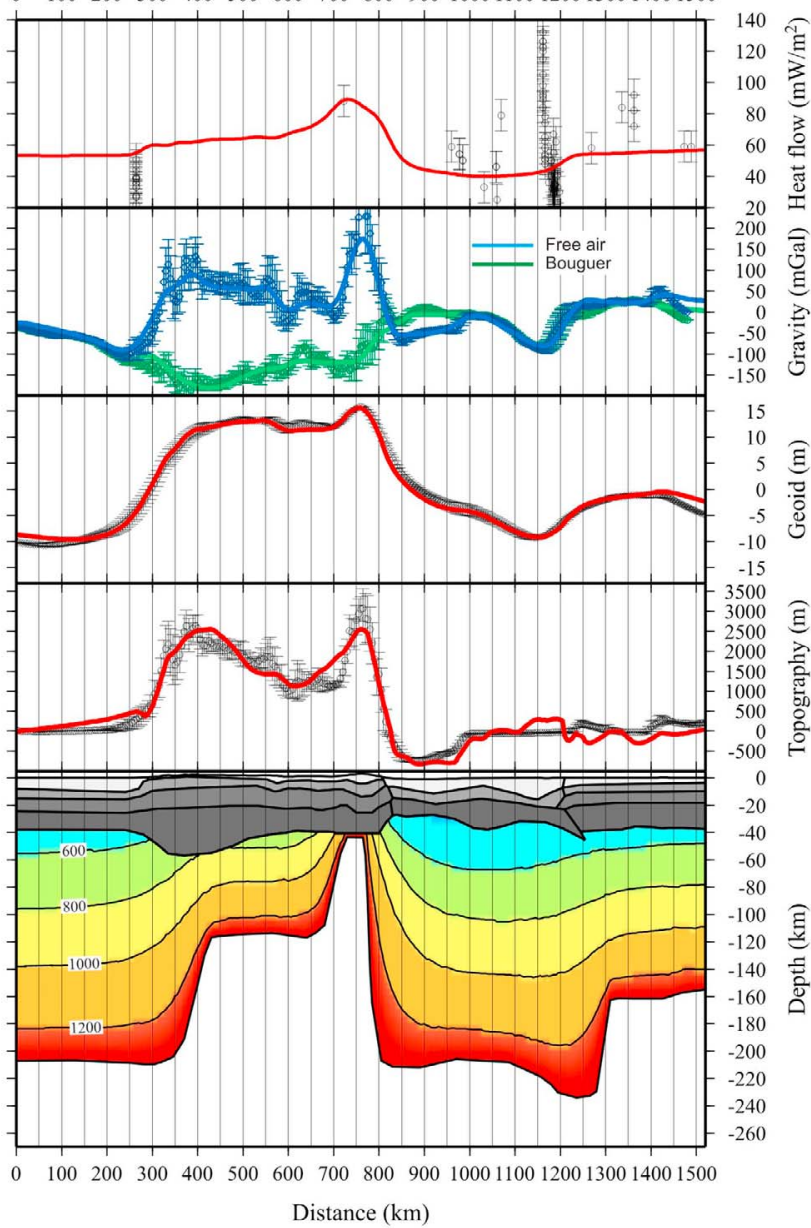

Figure 7. Models without root under the Alborz Mountains. (a) Model of Profile I eliminating the crustal root and reducing the depths of the other inner crustal interfaces correspondingly. Strong effects are visible for topography and geoid. (b) Reducing extremely the lithospheric thickness and deepening again the inner crustal interfaces allows explaining roughly the data. However, this model is geologically not acceptable. 
results show a thickness of $\sim 55 \mathrm{~km}$ for the Alborz Mountains which is compatible with Abbassi et al. [2010] and Radjaee et al. [2010].

[39] In the Zagros Mountains and central Iran regions, Paul et al. [2006] propose a crustal model (hereafter we call it "Paul_1 model") along a $620 \mathrm{~km}$ long profile coinciding nearly with the first half part of our profile III. They propose also a density model compatible with the Bouguer anomaly and their seismic data sets. In the Paul_1 model, the maximum crustal thickness of about $70 \mathrm{~km}$ is located $50-90 \mathrm{~km}$ NE of the surface exposure of the MZT, exactly beneath the low topography of SSZ. They interpret this very large thickness found only over a small distance, by overthrusting of the Arabia margin crust by the crust of central Iran along the MZRF. We tested this crustal model in the first half part of our profile III (Figure 5g), modifying also the lithospheric thickness in order to get the best possible data fit. Lithospheric thicknesses change also slightly in areas where crustal thickness does not change, since the densities of certain crustal layers were changed. As should be expected, we obtained a good fit of gravity anomalies, but topography and, more important, geoid undulations are not well fit (see Table 3 for misfit between measured and calculated data). Manaman and Shomali [2010] by tomographic inversion of data from the same experiment as Paul et al., got a maximum of $65 \mathrm{~km}$ Moho depth located partly beneath the high topography of the MZT, partly beneath the SSZ, a model that is more compatible with our results.

[40] Paul et al. [2010] published another model (hereafter named "Paul_2") which coincides in its northeastern part (100-420 km [Paul et al., 2010, Figure 3]) with our profile I $(500-820 \mathrm{~km}$, Figure 3). Between 150 and $500 \mathrm{~km}$ of our profile, model Paul_2 continues in a different direction. We tested also this model with our method (Figure 3g), using the part of Paul 2 away from our line for the Arabian Platform. The data fit for model Paul_2 is better than that for Paul_1, but there is still some misfit in the topography. The better fit is due to a thinner crust in Paul_2 than for Paul_1, probably related to a larger $V_{p} / V_{s}$ ratio used for this model.

[41] At crustal scale, the most important result is the thickness of up to $55 \mathrm{~km}$ beneath the Alborz Mountains indicating a pronounced crustal root. Since some previous studies argued for the absence of a root under the Alborz, we tested different models to see whether it is possible to explain the data without a root beneath the Alborz. However, we found that it is impossible to fit the calculated data to the measured ones with a geologically reasonable model. Figure 7a shows the effect of cutting the root under the Alborz on the modeling results of profile I, and Figure $7 \mathrm{~b}$ shows our best attempt to fit the data by keeping the Alborz rootless. The fit to the data is similar to the model with thickened Moho (Table 3). However, the upper and middle crustal layers still have to be thicker than normal and the eliminating the crustal root has to be compensated by an extreme thinning of the lithosphere, the asthenosphere touching nearly the base of the crust. This adjustment is possible since the mass deficit due to crustal thickening could be replaced at a similar depth by another mass deficit due to hot asthenosphere. It is, however, clear that such a thin lithosphere is geologically not acceptable. The temperatures in the lower crust should produce large-scale melting and accompanying volcanism that are not observed in the vicinity of profile I. Therefore, we conclude that thickening of the crust underneath the Alborz Mountains is necessary to explain all our data in a common model.

[42] The study by Dehghani and Makris [1984] is one of the main references that mentions a rootless Alborz. However, in the gravity data that they used, no data exist for the Alborz Mountains. Therefore, the depth of less than $35 \mathrm{~km}$ for the Moho in this region that they have calculated may well be due to the effect of data interpolation between the northern and southern side of the Alborz where the crust is thinner. In a recent work, Sodoudi et al. [2009] obtain a thin $(\sim 90 \mathrm{~km})$ lithosphere in this area in good agreement with our results. Their crustal thickness is $47 \mathrm{~km}$ for central Iran and $54 \mathrm{~km}$ for the Alborz which is close to our results $(55 \mathrm{~km}$ for the Moho thickness in the Alborz). Nevertheless, they claim that the root under the Alborz is missing. Also Abbassi et al. [2010] obtain a crustal thickness of $58 \mathrm{~km}$ with receiver function analysis. We believe therefore that the existence of a crustal root under the Alborz is very likely.

\section{Conclusions}

[43] Three the modeled profiles show the following main characteristics:

[44] 1. Crustal roots with thicknesses $55-60 \mathrm{~km}$ occur underneath the Zagros and Alborz mountains. A less pronounced but visible root underneath the Kopet-Dagh $(48 \mathrm{~km})$.

[45] 2. Crustal thicknesses of near $40 \mathrm{~km}$ occur below the Central Iran Plateau and the Turan Platform.

[46] 3, Strong thinning of the crust under the South Caspian block occurs with increasing thickness northward toward the Apsheron-Balkan Sill.

[47] 4. Thin lithosphere occurs under the northern part of the Zagros and the Central Iran (100-120 km).

[48] 5. Thick lithosphere of 160-190 km occurs beneath the Turan Platform and of 210-240 km occurs underneath the Arabian Platform as well as under the South Caspian block where the thickness increases toward the ApsheronBalkan Sill, indicating, together with the observed seismic activity, active subduction of the South Caspian block toward the N-NW.

[49] 6. No evidence for active subduction occurs further east, beneath the Kopet Dagh. This observation can be explained by a very rigid lithosphere in the South Caspian block due to a combination of very thick lithosphere and thin, probably oceanic crust or highly thinned continental one. Surrounding this block, relatively standard continental lithosphere accommodates compressive stresses by internal deformation.

[50] Acknowledgments. We thank A. Soltanpour at National Cartographic Center of Iran for his consultant. The presented work has profited from a Ph.D. grant attributed to the first author by the French Embassy in Iran. It is an integral part of the DARIUS Program that offered also financial support. Figures were created with GMT [Wessel and Smith, 1995]. Two anonymous reviewers really helped to improve considerably the first version of the manuscript.

\section{References}

Abbassi, A., A. Nasrabadi, M. Tatar, F. Yaminifard, M. R. Abbassi, D. Hatzfeld, and K. Priestley (2010), Crustal velocity structure in 
the southern edge of the Central Alborz (Iran), J. Geodyn., 49(2), 68-78, doi:10.1016/j.jog.2009.09.044.

Afonso, J. C., G. Ranalli, and M. Fernàndez (2005), Thermal expansivity and elastic properties of the lithospheric mantle: Results from mineral physics of composites, Phys. Earth Planet. Inter., 149(3-4), 279-306, doi:10.1016/j.pepi.2004.10.003.

Al-Damegh, K., E. Sandvol, A. Al-Lazki, and M. Barazangi (2004), Regional seismic wave propagation ( $\mathrm{Lg}$ and $\mathrm{Sn}$ ) and $\mathrm{Pn}$ attenuation in the Arabian Plate and surrounding regions, Geophys. J. Int., 157(2), 775-795, doi:10.1111/j.1365-246X.2004.02246.x.

Alavi, M. (1996), Tectonostratigraphic synthesis and structural style of the Alborz Mountain system in northern Iran, J. Geodyn., 21(1), 1-33, doi:10.1016/0264-3707(95)00009-7.

Alekseev, A. S., A. V. Belonosova, I. A. Burmakov, G. V. Krasnopevtseva N. N. Matveeva, G. I. Nersessov, N. I. Pavlenkova, V. G. Romanov, and V. Z. Ryaboy (1973), Seismic studies of low-velocity layers and horizontal inhomogeneities within the crust and upper mantle on the territory of the U.S.S.R, Tectonophysics, 20, 47-56, doi:10.1016/0040-1951(73) 90095-4.

Alinaghi, A., I. Koulakov, and H. Thybo (2007), Seismic tomographic imaging of $\mathrm{P}$ - and $\mathrm{S}$-waves velocity perturbations in the upper mantle beneath Iran, Geophys. J. Int., 169(3), 1089-1102, doi:10.1111/j.1365246X.2007.03317.x.

Allen, M. B., S. J. Vincent, G. I. Alsop, A. Ismail-zadeh, and R. Flecker (2003), Late Cenozoic deformation in the south Caspian region: Effects of a rigid basement block within a collision zone, Tectonophysics, 366(3-4), 223-239, doi:10.1016/S0040-1951(03)00098-2.

Allen, M. B., J. Jackson, and R. Walker (2004), Late Cenozoic reorganization of the Arabia-Eurasia collision and the comparison of short-term and long-term deformation rates, Tectonics, 23, TC2008, doi:10.1029/ 2003TC001530.

Artyushkov, E. V. (2007), Formation of the superdeep South Caspian Basin: Subsidence driven by phase change in continental crust, Russ. Geol. Geophys., 48, 1002-1014, doi:10.1016/j.rgg.2007.11.007.

Ashtari, M., D. Hatzfeld, and N. Kamalian (2005), Microseismicity in the region of Tehran, Tectonophysics, 395(3-4), 193-208, doi:10.1016/j. tecto.2004.09.011

Asudeh, I. (1982), Seismic structure of Iran from surface and body wave data, Geophys. J. R. Astron. Soc., 71, 715-730.

Barrier, E., and B. Vrielynck (2008), Palaeotectonic maps of the Middle East, in Tectono-Sedimentary-Palinspastic Maps From Late Norian to Piacenzian, Atlas of 14 Maps, scale 11:18,500,000, Comm. for the Geol. Map of the World, UNESCO, Geneva. (Available at http://www. ccgm.org.)

Barrier, E., B. Vrielynck, M.-F. Brunet, F. Bergerat, and M. Sosson (2008), Toward a model of tectonic evolution of the Middle East since Mesozoic, paper presented at International Geological Congress, Oslo, 6-14 Aug.

Belov, A. A. (1981), Tectonic History of the Alpine Fold Belt in the Paleozoic [in Russian], Nauka, Moscow.

Berberian, M. (1983), The southern Caspian: A compressional depression floored by trapped, modified oceanic crust, Can. J. Earth Sci., 20, 163-183, doi:10.1139/e83-015.

Berberian, M., and G. C. P. King (1981), Towards a paleogeography and tectonic evolution of Iran, Can. J. Earth Sci., 18, 210-265, doi:10.1139/e81-019.

Bird, P. (1978), Finite element modelling of the lithospheric deformation: The Zagros collision orogeny, Tectonophysics, 50, 307-336, doi:10.1016/0040-1951(78)90140-3.

Bowin, C. (1991), The Earth's gravity field and plate tectonics, Tectonophysics, 187, 69-89, doi:10.1016/0040-1951(91)90414-N.

Brunet, M.-F., M. V. Korotaev, A. V. Ershov, and A. M. Nikishin (2003), The South Caspian Basin: A review of its evolution from subsidence modelling, Sediment. Geol., 156(1-4), 119-148, doi:10.1016/S00370738(02)00285-3.

Brunet, M.-F., J. W. Granath, and M. Wilmsen (2009), South Caspian to central Iran basins: Introduction, Geol. Soc. Spec. Publ., 312, 1-6, doi:10.1144/SP312.1

Chapman, M. E. (1979), Techniques for interpretation of geoid anomalies, J. Geophys. Res., 84, 3793-3801, doi:10.1029/JB084iB08p03793.

Davoudzadeh, M., and K. Schmidt (1984), A review of the Mesozoic paleogeography and paleotectonic evolution of Iran, Neues Jahrb. Geol. Palaeontol. Abh., 168, 182-207.

Dehghani, G., and J. Makris (1984), The gravity field and crustal structure of Iran, Neues Jahrb. Geol. Palaeontol. Abh., 168, 215-229.

Devlin, W. J., J. M. Cogswell, G. M. Gaskins, G. H. Isaksen, D. M. Pitcher, D. P. Puls, K. O. Stanley, and G. R. T. Wall (1999), South Caspian Basin: Young, cool and full of promise, GSA Today, 9(7), 1-9.

Doloei, J., and R. Roberts (2003), Crust and uppermost mantle structure of Tehran region from analysis of teleseismic $\mathrm{P}$ waveform receiver func- tions, Tectonophysics, 364(3-4), 115-133, do1:10.1016/S0040-1951(03) 00049-0.

Egan, S. S., J. Mosar, M.-F. Brunet, and T. Kangarli (2009), Subsidence and uplift mechanisms within the South Caspian Basin: Insights from the onshore and offshore Azerbaijan region, Geol. Soc. Spec. Publ., 312, 219-240, doi:10.1144/SP312.11.

Garzanti, E., and M. Gaetani (2002), Unroofing history of Late Palaeozoic magmatic arcs within the 'Turan Plate' (Tuarkyr, Turkmenistan), Sediment. Geol., 151, 67-87, doi:10.1016/S0037-0738(01)00231-7.

Glumov, I. F., Y. P. Malovitskiy, A. A. Novikov, and B. V. Senin (2004), Regional Geology and Oil and Gas Content of Caspian Sea [in Russian], Nedra, Moscow.

Golonka, J. (2007), Geodynamic evolution of the South Caspian Basin, in Oil and Gas of the Greater Caspian Area, edited by P. O. Yilmaz and G. H. Isaksen, AAPG Stud. Geol., 55, 17-41.

Granath, J. W., K. A. Soofi, O. W. Baganz, and E. Bagirov (2007), Gravity modeling and its implications to the tectonics of the South Caspian Basin in Oil and Gas of the Greater Caspian Area, edited by P. O. Yilmaz and G. H. Isaksen, AAPG Stud. Geol., 55, 43-46.

Green, T., N. Abdullayev, J. Hossac, G. Riley, and A. M. Roberts (2009), Sedimentation and subsidence in the South Caspian Basin, Azerbaijan, Geol. Soc. Spec. Publ., 312, 241-260, doi:10.1144/SP312.12.

Guest, B., A. Guest, and G. Axen (2007), Late Tertiary tectonic evolution of northern Iran: A case for simple crustal folding, Global Planet. Change, 58(1-4), 435-453, doi:10.1016/j.gloplacha.2007.02.014.

Hafkenscheid, E., M. J. R. Wortel, and W. Spakman (2006), Subduction history of the Tethyan region derived from seismic tomography and tectonic reconstructions, J. Geophys. Res., 111, B08401, doi:10.1029/ 2005JB003791.

Hatzfeld, D., M. Tatar, K. Priestley, and M. Ghafory-Ashtiany (2003), Seismological constraints on the crustal structure beneath the Zagros Mountain belt (Iran), Geophys. J. Int., 155(2), 403-410, doi:10.1046/ j.1365-246X.2003.02045.X.

Hessami, K., F. Jamali, and H. Tabassi (2003), Major Active Faults of Iran, Int. Inst. of Earthquake Eng. and Seismol., Tehran.

Hollingsworth, J., J. Jackson, R. Walker, M. R. Gheitanchi, and M. J. Bolourchi (2006), Strike-slip faulting, rotation, and along-strike elongation in the Kopeh Dagh mountains, NE Iran, Geophys. J. Int., 166, 1161-1177, doi:10.1111/j.1365-246X.2006.02983.x.

Hollingsworth, J., J. Jackson, R. Walker, and H. Nazari (2008), Extrusion tectonics and subduction in the eastern south Caspian region since 10 Ma, Geology, 36, 763-766, doi:10.1130/G25008A.1

Jackson, J., J. Haines, and W. Holt (1995), The accommodation of ArabiaEurasia plate convergence in Iran, J. Geophys. Res., 100(B8), 15,20515,219, doi:10.1029/95JB01294.

Jackson, J., K. Priestley, M. Allen, and M. Berberian (2002), Active tectonics of the South Caspian Basin, Geophys. J. Int., 148(2), 214-245.

Kaviani, A., A. Paul, E. Bourova, D. Hatzfeld, H. Pedersen, and M. Mokhtari (2007), A strong seismic velocity contrast in the shallow mantle across the Zagros collision zone (Iran), Geophys. J. Int., 171(1), 399-410, doi:10.1111/j.1365-246X.2007.03535.x.

Kaz'min, V. G., and N. F. Tikhonova (2006), Late Cretaceous-Eocene marginal seas in the Black Sea-Caspian region: Paleotectonic reconstructions, Geotectonics, Engl. Transl., 40, 169-182, doi:10.1134/ S0016852106030022.

Knapp, C. C., J. H. Knapp, and J. A. Connor (2004), Crustal-scale structure of the South Caspian Basin revealed by deep seismic reflection profiling, Mar. Pet. Geol., 21(8), 1073-1081, doi:10.1016/j.marpetgeo.2003.04.002.

Lachenbruch, A. H., and P. Morgan (1990), Continental extension, magmatism and elevation; formal relations and rules of thumb, Tectonophysics, 174, 39-62, doi:10.1016/0040-1951(90)90383-J.

Lemoine, F. G., N. K. Pavlis, S. C. Kenyon, R. H. Rapp, E. C. Pavlis, and B. F. Chao (1998), New high-resolution model developed for Earth's gravitational field, Eos Trans. $A G U, 79(9), 113$, doi:10.1029/ 98EO00076.

Lyberis, N., and G. Manby (1999), Oblique to orthogonal convergence across the Turan Block in the post-Miocene, AAPG Bull., 83, 11351160

Maksimov, S. P. (Ed.) (1992), Kazakhstan and Middle Asia, Book 3, Platform Mantle of the Epi-Paleozoic Plates and Depressions of Middle Asia and South Kazakhstan [in Russian], vol. 6, 148 pp., Nedra, Moscow.

Mamedov, P. (2004), Genesis and seismic stratigraphic model of the south Caspian megabasin architecture, in South Caspian Basin: Geology, Geophysics, Oil and Gas Content, Special Issue Papers, 32nd International Geological Congress, Florence, Italy, edited by A. A. Ali-Zadeh, p. 332, Nafta, Baku.

Manaman, N. S., and H. Shomali (2010), Upper mantle S-velocity structure and Moho depth variations across Zagros belt, Arabian-Eurasian plate 
boundary, Phys. Earth Planet. Inter., 180(1-2), 92-103, doi:10.1016/j. pepi.2010.01.011.

Manaman, N. S., H. Shomali, and H. Koyi (2011), New constraints on upper-mantle S-velocity structure and crustal thickness of the Iranian plateau using partitioned waveform inversion, Geophys. J. Int., 184, 247-267, doi:10.1111/j.1365-246X.2010.04822.x.

Mangino, S., and K. Priestley (1998), The crustal structure of the southern Caspian region, Geophys. J. Int., 133(3), 630-648, doi:10.1046/j.1365246X.1998.00520.x.

Masson, F., Y. Djamour, S. Van Gorp, J. Chéry, M. Tatar, F. Tavakoli, H. Nankali, and P. Vernant (2006), Extension in NW Iran driven by the motion of the South Caspian Basin, Earth Planet. Sci. Lett., 252(1-2), 180-188, doi:10.1016/j.eps1.2006.09.038.

Milanovsky, E. E. (1991), Geology of the USSR, Part 3 [in Russian], 272 pp., Moscow Univ. Press, Moscow.

Molinaro, M., H. Zeyen, and X. Laurencin (2005a), Lithospheric structure beneath the south-eastern Zagros Mountains, Iran: Recent slab breakoff?, Terra Nova, 17(1), 1-6, doi:10.1111/j.1365-3121.2004.00575.x.

Molinaro, M., P. Leturmy, J.-C. Guézou, and D. Frizon de Lamotte (2005b), The structure and kinematics of the south-eastern Zagros fold-thrust belt, Iran: From thin-skinned to thick-skinned tectonics, Tectonics, 24, TC3007, doi:10.1029/2004TC001633.

Mooney, W. D. (1999), Crustal and upper mantle seismic velocity structure of the former USSR, paper presented at 21st Seismic Research Symposium, Dep. of Defense, Las Vegas, Nev.

Natal'ina, B. A., and A. M. C. Sengör (2005), Late Palaeozoic to Triassic evolution of the Turan and Scythian platforms: The pre-history of the Palaeo-Tethyan closure, Tectonophysics, 404, 175-202, doi:10.1016/j. tecto.2005.04.011.

Nikishin, A. M., S. Cloetingh, M.-F. Brunet, R. Stephenson, S. N. Bolotov, and A. V. Ershov (1998a), Scythian Platform and Black Sea region: Mesozoic -Cenozoic tectonic and dynamics, in Peri-Tethys Memoir 3: Stratigraphy and Evolution of Peri-Tethyan Platforms, edited by S. Crasquin-Soleau and E. Barrier, Mem. Mus. Natl. Hist. Nat., 177, $163-176$.

Nikishin, A. M., et al. (1998b), Scythian platform: Chronostratigraphy and polyphase stages of tectonic history, in Peri-Tethys Memoir 3. Stratigraphy and Evolution of Peri-Tethyan Platforms, edited by S. Crasquin-Soleau and E. Barrier, Mem. Mus. Natl. Hist. Nat., 177 , 151-162.

Nikishin, A. M., P. A. Ziegler, D. I. Panov, B. P. Nazarevich, M.-F. Brunet R. A. Stephenson, S. N. Bolotov, M. V. Korotaev, and P. L. Tikhomirov (2001), Mesozoic and Cenozoic evolution of the Scythian PlatformBlack-Sea-Caucasus domain, in Peri-Tethys Memoir 6: Peri-Tethyan Rift/Wrench Basins and Passive Margins, edited by P. A. Ziegler et al., Mem. Mus. Natl. Hist. Nat., 186, 295-346.

Okaya, N., S. Cloetingh, and S. Mueller (1996), A lithospheric cross section through the Swiss Alps (part II): Constraints on the mechanical structure of a continent-continent collision zone, Geophys. J. Int., 127, 399-414, doi:10.1111/j.1365-246X.1996.tb04729.x.

Omrani, J., P. Agard, H. Whitechurch, M. Benoit, G. Prouteau, and L. Jolivet (2008), Arc-magmatism and subduction history beneath the Zagros Mountains, Iran: A new report of adakites and geodynamic consequences, Lithos, 106(3-4), 380-398, doi:10.1016/j. lithos.2008.09.008.

Paul, A., A. Kaviani, D. Hatzfeld, J. Vergne, and M. Mokhtari (2006), Seismological evidence for crustal-scale thrusting in the Zagros mountain belt (Iran), Geophys. J. Int., 166(1), 227-237, doi:10.1111/j.1365246X.2006.02920.x

Paul, A., D. Hatzfeld, A. Kaviani, M. Tatar, and C. Péquegnat (2010), Seismic imaging of the lithospheric structure of the Zagros mountain belt (Iran), Geol. Soc. Spec. Publ., 330, 5-18, doi:10.1144/SP330.2.

Pavlis, N. K., S. A. Holmes, S. C. Kenyon, and J. K. Factor (2008), An Earth gravitational model to degree 2160: EGM2008, paper presented at General Assembly of the European Geosciences Union, Vienna, Austria, 13-18 April.

Pollack, H. N., S. J. Hurter, and J. R. Johnson (1993), Heat flow from the Earth's interior: Analysis of the global data set, Rev. Geophys., 31(3), 267-280, doi:10.1029/93RG01249.

Priestley, K., and D. McKenzie (2006), The thermal structure of the lithosphere from shear wave velocities, Earth Planet. Sci. Lett., 244(1-2), 285-301, doi:10.1016/j.epsl.2006.01.008.

Radjaee, A. H., M. Mokhtari, K. Priestley, and D. Hatzfeld (2007), Variation of Moho depth in the central Alborz [in Persian], Geosci. Sci. Q. J., 16(64), 136-147.

Radjaee, A. H., D. Rham, M. Mokhtari, M. Tatar, K. Priestley, and D. Hatzfeld (2010), Variation of Moho depth in the central part of the Alborz Mountains, northern Iran, Geophys. J. Int., 181(1), 173-184, doi:10.1111/j.1365-246X.2010.04518.x.
Ritz, J.-F., H. B. Nazari, A. Ghassemi, R. Salamati, A. Shafei, S. Solaymani, and P. Vernant (2006), Active transtension inside central Alborz: A new insight into northern Iran-southern Caspian geodynamics, Geology, 34(6), 477-490, doi:10.1130/G22319.1.

Saintot, A., R. Stephenson, S. Stovba, M.-F. Brunet, and T. Yegorova (2006), The evolution of the southern margin of Eastern Europe (Eastern European and Scythian platforms) from the latest Precambrian-Early Palaeozoic to the Early Cretaceous, Mem. Geol. Soc., 32, 481-505, doi:10.1144/GSL.MEM.2006.032.01.30.

Sandwell, D. T., and W. H. F. Smith (1997), Marine gravity anomalies from GEOSAT and ERS-1 satellite altimetry, J. Geophys. Res., 102 (B5), 10,039-10,054, doi:10.1029/96JB03223.

Sandwell, D. T., and W. H. F. Smith (2009), Global marine gravity from retracked Geosat and ERS-1 altimetry: Ridge segmentation versus spreading rate, J. Geophys. Res., 114, B01411, doi:10.1029/ 2008JB006008.

Sengör, A. M. C. (1990), A new model for the late Palaeozoic-Mesozoic tectonic evolution of Iran and implications for Oman, Geol. Soc. Spec. Publ., 49, 797-831, doi:10.1144/GSL.SP.1992.049.01.49.

Sengör, A. M. C., Y. Yilmaz, and O. Sungurlu (1984), Tectonics of the Mediterranean Cimmerides: Nature and evolution of the western termination of Paleo-Tethys, Geol. Soc. Spec. Publ., 17, 77-112, doi:10.1144/ GSL.SP.1984.017.01.04.

Snyder, D. B., and M. Barazangi (1986), Deep crustal structure and flexure of the Arabian plate beneath the Zagros collisional mountain belt as inferred from gravity observations, Tectonics, 5(3), 361-373, doi:10.1029/TC005i003p00361.

Sodoudi, F., X. Yuan, R. Kind, B. Heit, and A. Sadidkhouy (2009), Evidence for a missing crustal root and a thin lithosphere beneath the Central Alborz by receiver function studies, Geophys. J. Int., 177(2), 733-742, doi:10.1111/j.1365-246X.2009.04115.x.

Stampfli, G. M., and G. D. Borel (2004), The TRANSMED transects in space and time: Constraints on the paleotectonic evolution of the Mediterranean domain, in The TRANSMED Atlas: The Mediterranean Region From Crust to Mantle, edited by W. Cavazza et al., pp. 53-80, Springer, Berlin.

Talwani, M., J. L. Worzel, and M. Landisman (1959), Rapid gravity computations for two-dimensional bodies with application to the Mendocino submarine fracture zone, J. Geophys. Res., 64, 49-59, doi:10.1029/ JZ064i001p00049.

Tatar, M. (2001), Étude sismotectonique de deux zones de collision continentale: Le Zagros Central et l'Alborz (Iran), Ph.D. thesis, Univ. de Grenoble, Grenoble, France.

Thomas, J. C., J. R. Grasso, R. Bossu, J. Martinod, and B. Nurtaev (1999), Recent deformation in the Turan and South Kazakh platforms, western central Asia, and its relation to Arabia-Asia and India-Asia collisions, Tectonics, 18, 201-214, doi:10.1029/1998TC900027.

Turcotte, D. L., and G. Schubert (1982), Geodynamics, 450 pp., John Wiley, New York.

Vernant, P. (2003), Cinématique actuelle et dynamique de 1'Iran: GPS et modélisation numérique, Ph.D. thesis, 254 pp., Univ. Montpellier 2, Montpellier, France.

Vernant, P., and J. Chery (2006), Mechanical modelling of oblique convergence in the Zagros, Iran, Geophys. J. Int., 165(3), 991-1002, doi:10.1111/j.1365-246X.2006.02900.x.

Vernant, P., F. Nilforoushan, J. Chéry, R. Bayer, Y. Djamour, F. Masson, H. Nankali, J. F. Ritz, M. Sedighi, and F. Tavakoli (2004a), Deciphering oblique shortening of central Alborz in Iran using geodetic data, Earth Planet. Sci. Lett., 223(1-2), 177-185, doi:10.1016/j.eps1.2004.04.017.

Vernant, P., et al. (2004b), Present-day crustal deformation and plate kinematics in the Middle East constrained by GPS measurements in Iran and northern Oman, Geophys. J. Int., 157(1), 381-398, doi:10.1111/j.1365246X.2004.02222.x.

Wessel, P., and W. H. F. Smith (1995), New version of the Generic Mapping Tools released, Eos Trans. AGU, 76, 329, doi:10.1029/95EO00198

Yegorkin, A. V., and B. A. Matushkin (1970), Crustal structure of the Caucasus and western central Asia based on geophysical sounding data, Int. Geol. Rev., 12(3), 281-290, doi:10.1080/00206817009475233.

Zamani, B., J. Angelier, and A. Zamani (2008), State of stress induced by plate convergence and stress partitioning in northeastern Iran, as indicated by focal mechanisms of earthquakes, J. Geodyn., 45, 120-132, doi:10.1016/j.jog.2007.07.003.

Zanchi, A., S. Zanchetta, E. Garzanti, M. Balini, F. Berra, M. Mattei, and G. Muttoni (2009a), The Cimmerian evolution of the Nakhlak-Anarak area, central Iran, and its bearing for the reconstruction of the history of the Eurasian margin, Geol. Soc. Spec. Publ., 312, 261-286, doi:10.1144/SP312.13.

Zanchi, A., S. Zanchetta, F. Berra, M. Mattei, E. Garzanti, S. Molyneux, A. Nawab, and J. Sabouri (2009b), The Eo-Cimmerian (Late? Triassic) 
orogeny in north Iran, Geol. Soc. Spec. Publ., 312, 31-55, doi:10.1144/ SP312.3.

Zeyen, H., and M. Fernàndez (1994), Integrated lithospheric modeling combining thermal, gravity and local isostasy analysis: Application to the NE Spanish Geotransect, J. Geophys. Res., 99, 18,089-18,102, doi:10.1029/94JB00898.

Zeyen, H., P. Ayarza, M. Fernàndez, and A. Rimi (2005), Lithospheric structure under the western African-European plate boundary: A transect across the Atlas Mountains and the Gulf of Cadiz, Tectonics, 24 TC2001, doi:10.1029/2004TC001639.

Zonenshain, L. P., and X. Le Pichon (1986), Deep basins of the Black Sea and Caspian Sea as remnants of Mesozoic back-arc basins, Tectonophysics, 123, 181-211, doi:10.1016/0040-1951(86)90197-6.
Zonenshain, L. P., M. I. Kuzmin, and L. M. Natapov (1990), Geology of the USSR: A Plate-Tectonic Synthesis, 242 pp., AGU, Washington, D. C.

V. E. Ardestani and S.-H. Motavalli-Anbaran, Institute of Geophysics, University of Tehran, PO Box 14155-6466 Tehran, Iran. (hani1380ir@ yahoo.com)

M.-F. Brunet, ISTeP, UMR 7193, CNRS, case 129, 4, place Jussieu, F-75252 Paris CEDEX 05, France.

H. Zeyen, UMR 8148 IDES, CNRS/Université Paris-Sud XI, Département des Sciences de la Terre, Bât. 504, F-91405 Orsay CEDEX, France. 